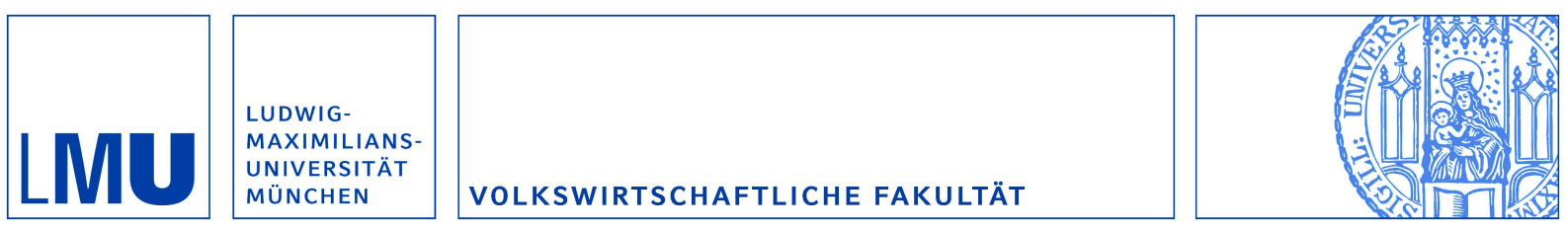

Schymik, Jan Simon:

Trade, Technologies, and the Evolution of Corporate Governance

Munich Discussion Paper No. 2015-9

Department of Economics

University of Munich

Volkswirtschaftliche Fakultät

Ludwig-Maximilians-Universität München

Online at https://doi.org/10.5282/ubm/epub.24871 


\title{
Trade, Technologies, and the Evolution of Corporate Governance
}

\author{
Jan Simon Schymik
}

June 2015

\begin{abstract}
Do international trade and technological change influence how firms create incentives for human capital? I present a model that incorporates agency problems into a framework with firm heterogeneity and human capital. My model indicates that trade liberalizations and skill-biased technological change alter the way how the largest firms in an economy incentivize their managers. Increases in managerial reservation wages lead to a reduction in corporate governance investments and a rise in performance compensation since monitoring managers becomes less efficient. Using data on CEO compensation and entrenchment opportunities in public industrial firms in the U.S., I document strong empirical regularities in support of the model predictions. Firms allow for more managerial entrenchment and offer larger CEO compensation when their industries become more open to trade or when production becomes more I.T. intensive.
\end{abstract}

JEL Classification: F1, F16, G34, J33, L22, O33

Keywords: international trade and firm organization, agency problems in international trade, endogenous managerial entrenchment, corporate governance and CEO compensation

\footnotetext{
『Department of Economics, University of Munich, E-mail: jan.schymik@econ.uni-muenchen.de I would like to thank the members of my dissertation committee Dalia Marin, Florian Englmaier, and Carsten Eckel for their guidance and support throughout. I am also particularly grateful to Daniel Baumgarten, Jean de Bettignies (discussant), Nick Bloom, Cheng Chen, Hans Gersbach, Luisa Herbst (discussant), Fabian Herweg, Norman Loeckel, Kalina Manova, Volker Nocke, Monika Schnitzer, Alexander Tarasov, Jan Tscheke and seminar audiences at Bonn (SFB TR15 Young Researcher Summer Workshop), EEA-ESEM Gothenburg 2013, Verein für Socialpolitik Düsseldorf 2013, SFB TR15 Tutzing, MGSE Colloquium Munich, EARIE Bocconi Milan 2014, European Trade Study Group Munich 2014, Econometric Society European Winter Meeting Cemfi Madrid 2014, and the ZEW Labor Seminar for their helpful comments. I thank René Bernard and Thomas Neuber for their superb research assistance. Financial support from the Deutsche Forschungsgemeinschaft through SFB TR15 and the European Commission under the FP7 Framework programme "Science, Innovation, Firms, and Markets in a Globalized World (SCIFI-GLOW)" is gratefully acknowledged.
} 


\section{Introduction}

During the last two decades, public firms in the U.S. increasingly created incentives for their executives with performance related compensation while improvements in corporate governance to prevent adverse managerial behavior have been rather scarce. According to an estimate, the median share of performance payments in S\&P 500 firms increased from 58 to 83 percent between 1992 and 2008. ${ }^{1}$ Moreover, governance provisions working in favor of managerial entrenchment typically have not been removed but rather augmented. The U.S. corporate governance index from Bebchuk et al. (2009) indicates that on average, entrenchment opportunities became inferior in public firms during the last two decades.

Besides these developments inside executive suites, the market environment has been changing substantially for these corporations. First, increasing globalization led to rises in the effective market size served by large U.S. firms. Second, technological change driven by the rapid development of information technologies induced productivity increases within I.T. using firms. Labor economists frequently argue that globalization and skill-biased technological change have been major triggers of increases in the level and the slope of compensation at the very top of the income distribution. ${ }^{2}$ However, the understanding how these developments affect the way how firms create incentives for human capital is rather scant. Why did firms not improve their quality of corporate governance over time to incentivize managers with better control mechanisms? In this paper, I study if changes in the market environment through international trade and technological change can influence the way how firms create incentives for human capital.

In the first part of the paper, I propose a model with heterogeneous firms and human capital that incorporates agency problems. In my model, firms make an ex ante investment decision on the level of corporate governance when they enter the market. Higher levels of corporate governance reduce agency problems as corporate governance allows for a better monitoring of prospective managers and therefore reduces the managers' incentives to behave adversely. Firms then match with agents which are employed as managers and agents employed as production workers, where the quality of production technologies and the skill level of the manager jointly determine the productivity of firms. Technologies and management skills are both complements such that a positive assortative assignment arises. To determine the distribution of managerial reservation wages in equilibrium, I borrow from the literature on the assignment of managers to firms and make use of the positive

\footnotetext{
${ }^{1}$ See Frydman and Jenter (2010) who document the historical development of U.S. executive compensation.

${ }^{2}$ See for instance Baldwin and Cain (2000) who study the roles of trade and technology for shifts in relative U.S. wages, Bell and Van Reenen (2013) who study the role of globalization on extreme wage inequality in top management or Cuñat and Guadalupe $(2005,2009)$ who study the effects of globalization on incentive provisions.
} 
assortative matching of management skills to production technologies (see Monte (2011), Gabaix and Landier (2008) or Terviö (2008)). An assignment implies that the marginal cost of a slightly higher skilled manager is equal to the marginal benefit of this manager in a competitive labor market equilibrium. Therefore, managerial reservation wages depend on the productivity of managers and thus on their individual skill level, the production technology of the firm and market characteristics. In addition to the upfront investment into the corporate governance quality, firms offer bonus payments to incentivize their managers to exert effort. While corporate governance and performance compensation act as substitutes regarding the provision of incentives, the managers' reservation wages impair this substitutability when higher demand for human capital constrains firms to compensate managers at higher levels. Consequently, firms competing for managers with the highest skill levels in the economy offer more performance compensation and leave more discretion to their human capital as they make lower ex ante investments into monitoring.

The paper proceeds with two comparative static exercises. First, I consider the effects of skill-biased technological change on corporate governance investments and performance payments in a closed economy setting. More specifically, I model skill-biased technological change as an increase in the effectiveness of production technologies leading to relatively larger benefits for higher skilled managers. Second, I extend the model to an open economy version with two symmetric countries and intra-industry trade (see also Monte (2011) who studies how trade and technological change affect the wage dispersion of human capital in a setting without agency problems). The open economy version of the model allows me to study how a trade integration, modeled as a trade cost reduction, affects firm decisions on the creation of incentives. Both, trade and skill-biased technological change raise the competition for the highest skilled managers in the economy. Better access to foreign markets for the largest firms in the economy and an increase in the effectiveness of production technologies both increase the marginal productivity of human capital and thus induce an upward shift in reservation wages at the top of the skill distribution. These increases in reservation wages induce companies to respond with a rise in performance payments leading to a crowding out of investments into corporate governance.

The comparative static analysis relates to two prominent and competing explanations for the rise of executive compensation during the previous decades: managerial power versus labor market competition. On the one hand, some economists argue that the rise of executive compensation is due to more powerful managers who can influence their compensation contracts and easily extract rents from the firm (see Bebchuk and Fried (2003)). On the other hand, another strand of literature claims that competition for managerial talent, induced by a larger market capitalization of firms, can account for the rise in executive pay (see Gabaix and Landier (2008) and Terviö (2008)). My model combines both strands: trade and new technologies induced changes in the market environment of firms. 
These changes have triggered a shift in the demand for managerial talent such that firms endogenously allowed for more managerial discretion and increased performance payments at the top.

In the second part of the paper, I construct a panel of large public industrial firms from the U.S. between 1993 and 2006 with information on managerial entrenchment opportunities and CEO compensation. Combined with information on trade openness and the importance of I.T. at the industry level, I empirically analyze the comparative statics of the model. My empirical results suggest that variation in firms' exposure to trade or I.T. leads to adjustments of corporate governance provisions and CEO compensation over time. I find that firms allow for more managerial entrenchment, proxied by the entrenchment index by Bebchuk et al. (2009), and offer higher CEO pay when their industries become more open to trade or when industries become more I.T. intensive. Both, trade openness and I.T. intensity are measured at the sectoral level, where trade openness is the share of exports relative to the domestic market size of the industry and the I.T. intensity is the fraction of I.T. investments in total capital formation of the industry. In order to address potential sources of endogeneity in measuring the effects of trade, I employ an instrumental variable strategy, where trade openness is instrumented with variation in ad valorem maritime transport costs and a real effective exchange rate basket of trading partner currencies.

This paper covers a question at the intersection of organizational and international economics and thus relates to various strands of the literature on the effects of trade and technological change on firm organization and corporate finance.

First, I contribute to the literature that considers incentive compensation in general equilibrium trade models. Wu (2011) and Chen (2014) focus on the managerial incentive provision in firms with moral hazard in general equilibrium models of intra-industry trade and firm heterogeneity à la Melitz (2003). Gersbach and Schmutzler (2014) show how the global integration of product and labor markets increases the heterogeneity of CEO remuneration in a model with Cournot competition. While these models study a tradeinduced dispersion of compensation, the focus of this paper is on the endogenous choice of the channel how firms offer incentives: either with investments into corporate governance or via performance compensation.

Second, the paper relates to the literature that links the decision to delegate authority inside firms to globalization and the technological frontier. Marin and Verdier (2008, 2012, 2014) show that globalization affects the delegation of formal and real authority in organizations. They embed the allocation of formal decision authority à la Aghion and Tirole (1997) into models of international trade and explain how economic integration leads to the delegation of power inside firms. However, since agents are infinitely risk-averse with 
respect to income, performance payments cannot be used to create incentives. Consequently, these models do not draw inferences on the choice between managerial discretion and performance pay. Additionally, the quality of managerial talent is homogenous such that variation across firms within industries is absent. Marin et al. (2015) investigate how the allocation of power inside firms is affected by offshoring managers or production tasks in a small open economy model. Caliendo and Rossi-Hansberg (2012) show that exporting firms increase the control span of managers and the number of management layers within their hierarchies after trade liberalizations. Acemoglu et al. (2007) analyze how technology diffusion affects firm decentralization. They argue that decision rights are more decentralized when private information of agents is crucial. Consequently, the delegation of authority is more likely when firms are relatively close to the technological frontier such that technologies are not public knowledge. Compared to their model, technologies play a different role in this chapter. While the quality of ideas and managerial skills are modeled as complementary inputs in my model, the complexity of technologies and the quality of the managerial talent is exogenous in their paper. I add an integrated view to this literature that considers both, the choice of corporate governance and performance payments which are subject to labor market outcomes. This allows to draw novel conclusions about the effects of trade and technological change on the substitution patterns between payments and governance to provide incentives.

Third, the empirical analysis in this paper relates to several empirical studies on the effects of product markets on either managerial power or incentive compensation. Here, the literature has primarily focused on the delegation of decision authority as a particular dimension of managerial power. Bloom et al. (2010) and Guadalupe and Wulf (2010) use data on the organization of firms to show how more import penetration leads to flatter firm hierarchies and more decentralized decision making. Marin and Verdier (2014) show that German and Austrian multinationals have a more decentralized organization when they are faced by a stronger trade exposure. Cuñat and Guadalupe (2005) consider the appreciation of the British Pound as a quasi-natural experiment to quantify the effect of product market competition on executive performance pay within a panel of British manufacturing firms. They find that the implied import competition shock led to a higher pay to performance sensitivity for managers in more open sectors.

Fourth, the paper is also methodically related to recent research on assignment models that consider corporate finance decisions of the firm. Eisfeldt and Kuhnen (2013) present a model where CEOs and firms form matches based on multiple characteristics to explain low turnover rates in an industry equilibrium. Bénabou and Tirole (2013) analyze the impact of labor market competition and skill-biased technological change on the structure of compensation in a Hotelling framework. They demonstrate that competition for talent shifts effort from less easily contractible tasks, like long-term investments, towards more 
easily contractible tasks. In addition Baranchuk et al. (2011), Edmans et al. (2009) and Falato and Kadyrzhanova (2012) develop industry equilibrium models with moral hazard problems to show how CEO compensation interacts with the industry environment of firms. Dicks (2012) establishes a role for corporate governance regulation in an industry equilibrium model with moral hazard and assignment of CEOs to firms. Acemoglu and Newman (2002) consider the impact of labor supply and demand on the corporate structure of firms and show how the outside option of production workers affects production worker monitoring.

The remainder of the paper is organized as follows. The model and the comparative static analyses are presented in the following section 2 . Section 3 describes the data, empirical modeling strategy and presents empirical results. Section 4 concludes.

\section{Model}

In this section, I present a theoretical model that allows to analyze how the market environment affects firms' decisions to provide incentives for managers. In the model, firms with heterogeneous production technologies compete for managers with heterogeneous levels of management skills. In order to produce output, managers need to exert effort. Since managerial effort is not directly observable, firm owners need to provide incentives with performance payments and ex ante investments in corporate governance to improve the monitoring of managers.

In the model, trade liberalizations and technological change increase the competition for management skills. This raises the reservation wages for the highest skilled managers and crowds out corporate governance investments. I show that these effects of trade liberalizations and technological change on the agency problems inside firms ultimately lead to a higher fraction of firms in the economy that do not invest in corporate governance.

I begin with a closed economy setting. I follow Acharya et al. (2013) in modeling the organization of firms subject to moral hazard. This agency problem inside the firm is subsequently introduced into an economy that is endowed with heterogeneous management skills and production technologies à la Monte (2011). Complementarities in the effectiveness of managerial skills and production technologies lead to a positive assortative matching of managers to production technologies which determines the reservation wages of managers and the level of corporate governance investments by firms. The equilibrium is then determined by labor market clearing and zero earnings for the cutoff firm in the economy.

The timing structure of the model is as follows: 
$t=0$ : All firms that want to enter the market make an upfront investment into the level of corporate governance $g \in[0,1]$ that they want to establish at their firm. Better corporate governance leads to more efficient control of their managers and thus to a closer alignment of the manager's incentives to the owner's interests.

$t=1$ : All firms that want to enter the market need to hire a manager. Owners make a 'take it or leave it' contract offer to a manager, taking into account the value of the manager's reservation wage. The prospective manager receives the offer which specifies a performance payment and the level of corporate governance investment chosen in $t=0$. This level of corporate governance allows a prospective manager to infer how likely it is to entrench himself in order to pursue personal goals. Managers in more weakly governed firms have a higher chance to remain uncaught when shirking such that their incentives are less closely aligned with the owners' interests. Managers may decide to accept or decline the offer depending on their respective reservation wage. Labor market clearing requires that the remaining agents that do not get an offer for a management position become production workers.

$t=2$ : After a manager accepts the offer, he chooses to either exert effort or to shirk. Whenever the manager chooses to shirk, the output production will fail. Whenever the manager chooses to spend effort, there is a positive chance that the firm produces output. The quality of corporate governance is introduced as a probability $g$ with that firm owners receive a signal on the expected production outcome. If the signal indicates a failure of output production, firm owners can displace a manager in order to obtain some liquidation rent.

$t=3$ : After the production occurred, all agents are compensated and profits are realized.

\subsection{Preferences and Economic Endowments}

Consider an economy that is populated by a mass of agents $L$. Agents can be employed as production workers or as managers. Agents differ in their level of management skills but they are equal in the skills that they provide as production workers. The distribution of managerial skills is described by $L(s)=L / s$, where $s \in[1, \infty)$ is the skill level and $L(s)$ is the measure of agents with management skills at least as good as skill level $s$. Agents that fill an occupation as production worker provide one efficiency unit of production labor, independently of their management skills.

Furthermore, there exists a mass of production technologies whose quality distribution is given by $G(z)=T / z$. Here, $z \in(0, \infty)$ is the quality of a technology and $G(z)$ is the measure of technologies that are at least as good as a technology with quality $z$. 
This implies that the number of available (however, bad) technologies is sufficient to accommodate any number of managers in equilibrium. All production technologies are owned by a mutual fund (the principal) that maximizes the individual profits of each firm and redistributes them equally across the population. ${ }^{3}$

Consumer preferences can be described by a C.E.S. utility function over a set of differentiated varieties $J$ and a term $\Phi$ that captures any personal costs and benefits that are related to the agency problem inside firms:

$$
U=\left[\int_{j \in J} y_{j}^{(\sigma-1) / \sigma} d j\right]^{\sigma /(\sigma-1)}+\Phi,
$$

where $y_{j}$ is the amount that is consumed of variety $j$ and $\sigma>1$ is the constant elasticity of substitution. ${ }^{4}$ The term $\Phi$ includes all personal costs and benefits from corporate governance and potential benefits from shirking which will be endogenized in the following subsection.

\section{$2.2 \quad$ Firms}

Firms need three inputs in order to exist and produce output: a production technology, a manager that exerts effort and production workers in proportion to the firm output. ${ }^{5}$ The productivity of a firm is determined by the quality of the production technology $z$ and the skill level $s$ of the manager. I assume that management skills and production technologies complement each other regarding the production of output. In particular, the unit costs of production are given as

$$
\varphi(z, s)=\frac{w}{z^{\kappa} s^{\mu}}
$$

where $w$ is the production labor wage. The parameter $\mu>0$ measures the influence of the manager's skill and the parameter $\kappa>0$ the impact of the production technology on firm productivity.

Firms charge a constant markup over their unit costs of production and a firm that

\footnotetext{
${ }^{3}$ This is a standard assumption in international trade with heterogeneous firms to abstract from any wealth effects among economic agents.

${ }^{4}$ This implies that consumers spend $x_{j}=X\left(p_{j} / P\right)^{1-\sigma}$ on each variety that is produced, where $P \equiv$ $\left[\int_{j \in J} p_{j}^{(1-\sigma)} d j\right]^{1 /(1-\sigma)}$ is the price index in the economy and $X$ the aggregate consumption expenditure.

${ }^{5}$ The occupational choice between production work and managerial work will be endogenized later, when an equilibrium is determined. Unlike in Melitz (2003), where the production labor supply is fixed and similar to $\mathrm{Wu}$ (2011), the allocation of agents into production worker jobs and managerial jobs endogenously pins down the supply of production labor.
} 
produces output obtains operating profits $Y(z, s)$ that are given as

$$
Y(z, s)=M\left(\frac{z^{\kappa} s^{\mu}}{w}\right)^{\sigma-1}
$$

The term $M \equiv \frac{1}{\sigma}\left(\frac{\sigma}{\sigma-1}\right)^{1-\sigma} X P^{\sigma-1}$ captures the size of the market from the perspective of an individual firm. Markets are large if the elasticity of substitution between varieties is low and the aggregate expenditure level $X$ or the price index $P$ are large.

However, firms can only produce output and obtain $Y(z, s)$ if their manager exerts effort. Managerial effort is not directly observable for outsiders which requires the provision of sufficient incentives for managers. This rationalizes firm investments into corporate governance in order to monitor managers or the offer of performance compensation in order to provide monetary incentives for managers.

Remember that firm owners make an upfront decision on their investment into the level of corporate governance $g \in[0,1]$ in period $t=0$. Investments in corporate governance are costly and generate linear personal costs $(m w) g .{ }^{6}$ These investment costs reflect the owners' ex-ante effort costs to set up a system in order to monitor managers ex-post.

In the following period $t=1$, each firm needs to hire a manager in order to become active on the market. A managerial contract specifies managerial compensation $r \geq 0$ and prospective managers can observe the level of corporate governance investments $g \in[0,1]$ that the firm has made in period $t=0$. Better corporate governance allows firms to identify and displace unproductive managers more easily. I model this in the following way. Before the surplus is realized, owners observe a signal on the expected firm surplus with probability $g$. After observing this signal, managers can be displaced and owners receive a fixed liquidation rent $l w{ }^{7}$ This liquidation rent induces firm owners to displace managers whenever they receive a negative signal on output production.

Managers can decide to either provide effort, in which case the output $Y(z, s)$ is realized with some positive probability $\varepsilon$. Alternatively, managers can choose to shirk which leads to the complete failure of production. Shirking is beneficial for managers as they can then obtain a private non-pecuniary benefit $b$ when they remain uncaught, i.e. when firm owners did not receive a signal. Therefore, a higher value of $g$ disciplines managers because higher investments in corporate governance decreases their expected benefits from shirking. All agents are risk neutral and protected by limited liability.

\footnotetext{
${ }^{6}$ I choose to express the costs and benefits of corporate governance in terms of the production labor wage rate $w$ in order to simplify the notation when I derive the equilibrium solution. This simplifies the characterization of an equilibrium in the open economy case and leaves the qualitative results of the comparative static analyses unaffected.

${ }^{7} \mathrm{An}$ empirical counterpart of this liquidation value could be the owner's benefits of a merger or the acquisition by another firm.
} 
The objective function for a firm with technology $z$ and management skill level $s$ is therefore given as

$$
\max _{r, g} \varepsilon(Y(z, s)-r(s))+(1-\varepsilon) \operatorname{lwg}(s)-\operatorname{mwg}(s) .
$$

In order to motivate a manager to work, the choice of his compensation $r(s)$ and the degree of corporate governance $g(s)$ inside the firm need to be incentive compatible such that

$$
\varepsilon r(s) \geq(1-g(s)) b
$$

Equation (5) shows that ex ante, corporate governance and performance pay are substitutes with respect to the provision of incentives. From the perspective of the manager, a stricter level of corporate governance reduces his chances to obtain private benefits such that incentive compatibility is achievable with lower levels of performance pay. Vice versa, more performance pay makes effort provision more attractive such that less control is required.

However, this substitutive relationship is impaired by the participation constraint. Managers are only willing to work for the firm if their expected earnings are at least as large as their reservation wages $u(s)$. This imposes a minimum payment requirement $u(s)$. The manager's expected income needs to give him at least his reservation wage such that the participation constraint requires

$$
\varepsilon r(s) \geq u(s)
$$

In order to make the analysis interesting, I make the following assumptions.

\section{Assumption.}

(1) $m w \in((1-\varepsilon) l w,(1-\varepsilon) l w+b)$ : the choice of $g$ is non-trivial. If corporate governance investments were cheaper, firms would always invest. If instead corporate governance investments were more expensive, corporate governance investments would never be profitable.

(2) $\varepsilon Y(z, s)>l w$ : owners have no incentive to displace the manager and obtain the liquidation value $l w$ when they do not observe the production outcome.

(3) $w<b$ : there are some firms in the economy that choose to invest in corporate governance such that there is variation in corporate governance across firms.

Given the assumptions from above, the optimal combination of remuneration $r$ and governance $g$ is summarized in the following proposition.

Proposition 1. A firm that employs a manager with skill level $s$ and a reservation wage $u(s)$ offers the manager a performance compensation of $r(s)=\frac{u(s)}{\varepsilon}$ whenever production 
succeeds and makes an upfront investment into the level corporate governance $g(s)=$ $1-\frac{u(s)}{b}$ if $u(s) \leq b$ and $g(s)=0$ if $u(s)>b$.

Proof. See Appendix.

Intuitively, the optimal incentive contract depends on the value of the manager's reservation wage. For managers that obtain a relatively large reservation wage $u(s)>b$, the incentive compatibility constraint becomes redundant since the compensation is already sufficiently large to incentivize the manager to work. This makes investments in corporate governance inefficient. For managers with a relatively low reservation wage $u(s) \leq b$, owners optimally choose the cheapest contract that keeps both constraints binding in equilibrium such that they set incentives with a mix between corporate governance and compensation. I refer to the appendix for a formal proof of proposition 1.

\subsection{Equilibrium}

In a next step, I establish the conditions that determine an equilibrium solution. This allows me to characterize the compensation of managers and corporate governance choices of firms in the economy. In an equilibrium, there is a stable assignment of management skills to production technologies. Moreover, labor markets must clear and only firms with expected non-negative profits will enter the market.

I begin with the assignment of managers to technologies to pin down the reservation wages of managers. Complementarities between production technologies and management skills in combination with a competitive labor market for managerial talent, lead to a positive assortative matching of management skill levels to production technologies, as it is standard in the assignment literature. ${ }^{8}$ This positive assortative matching keeps the model tractable since it implies that the measure of the upper tail of the skill distribution and the measure of the upper tail of the technology distribution need to be of equal size for each matched firm pair $(s, z)$ such that

$$
L / s=T / z \quad \Leftrightarrow \quad z=t s
$$

where $t \equiv T / L$ is a relative measure of the technology size in the economy. In order to pin down the reservation wages $u(s)$, I make use of a standard assignment equation as

\footnotetext{
${ }^{8}$ See for example Gabaix and Landier (2008) or Terviö (2008). Furthermore, consider the following intuitive argument: Suppose there were two technology-skill matches $\left(z_{1}, s_{2}\right)$ and $\left(z_{2}, s_{1}\right)$ that form firms in equilibrium with $z_{1}<z_{2}$ and $s_{1}<s_{2}$. The aggregate surplus could be increased by making the manager with skill $s_{1}$ the head of the firm with production technology $z_{1}$ and the other manager with skill $s_{2}$ the head of the firm with $z_{2}$ instead. Since any competitive equilibrium is efficient, this is a contradiction.
} 
in Gabaix and Landier (2008) or Monte (2011). In equilibrium, the marginal cost of a slightly better manager equals the marginal benefit of a slightly better manager from the perspective of the firm: ${ }^{9}$

$$
\frac{\partial \varepsilon Y(z, s)}{\partial s}_{\mid z=z(s)}=u^{\prime}(s)
$$

Differentiating the surplus (3) with respect to $s$ and plugging $z(s)=t s$ in, gives the reservation wages:

$$
u(s)=\varepsilon M\left(\frac{t^{\kappa}}{w}\right)^{\sigma-1} \frac{\mu}{\kappa+\mu}\left(s^{(\kappa+\mu)(\sigma-1)}-s_{c}^{(\kappa+\mu)(\sigma-1)}\right)+w,
$$

where $s_{c}$ is the level of management skills of the marginal manager in the economy. This manager runs the least productive firm that is active in the market and earns a wage that is equal to the production worker wage rate $w$. Intuitively, the compensation of managers increases with their skill $s$, market size $M$, the relative technological endowment of the economy $t$ and the contribution of managerial talent to firm productivity $\frac{\mu}{\kappa+\mu}$. Furthermore, reservation wages fall with the skill level of the marginal manager $s_{c}$.

Moreover, only firms with positive expected net earnings will enter the market. Consider the firm in the market with zero expected net earnings. Due to the positive assortative assignment of production technologies to management skills, this marginal firm employs the least-skilled manager with management skills $s_{c}$. All agents with management skills below $s_{c}$ will be employed as production workers and earn the production worker wage rate $w$. Consequently, the marginal manager must be indifferent between an occupation as production worker with a fixed wage rate $w$ or an occupation as a manager with a performance payment $r$ whenever output production occurs such that his reservation wage is given by $u\left(s_{c}\right)=w$. According to proposition 1 , the contract offered by the marginal firm is characterized by a performance payment $r\left(s_{c}\right)=w / \varepsilon$ and the highest level of governance investments in the economy $g\left(s_{c}\right)=1-w / b$. This gives rise to the following zero cutoff earnings condition which ensures that only firms with nonnegative net earnings will be active in the market:

$$
X=\frac{\sigma L \lambda w}{\psi} s_{c}^{-1}
$$

where $\psi \equiv 1-(\sigma-1)(\kappa+\mu)$ and the term $\lambda \equiv((1-w / b)(m-(1-\varepsilon) l)+1)$ contains the net cost of corporate governance for the marginal firm plus one. ${ }^{10}$ Intuitively, this curve is downward sloping in the management skill $s_{c}$ since a higher management skill level $s_{c}$

\footnotetext{
${ }^{9}$ Note, that the marginal cost of the manager do not include any marginal corporate governance costs since corporate governance investments have been made in $t=0$ and are therefore sunk in the hiring stage $t=1$.

${ }^{10}$ These net costs of corporate governance comprise the monitoring costs $(1-w / b) m$ net of the expected liquidation rent $(1-w / b)(1-\varepsilon) l$.
} 
would increase the productivity of the marginal firm. In order to restore zero earnings of the marginal firm, the aggregate expenditure level in the economy $X$ must decrease.

Next, I consider the clearing of labor markets. In contrast to the classical Melitz (2003) model with heterogeneous firms, the labor supply is not fix in my model since the mass of production workers depends on the number of managers and the number of firms in the economy, respectively. The labor market clears when the aggregate expenditure on production workers that is required to produce the aggregate output of all active firms equals the aggregate earnings of those production workers. This gives rise to the following condition that must hold in equilibrium:

$$
X=\frac{L w}{\varepsilon} \frac{\sigma}{\sigma-1}\left(1-s_{c}^{-1}\right) .
$$

The function (10) is upward sloping in $s_{c}$. Intuitively, an increase in $s_{c}$ increases the supply of production production workers since less agents in the economy are employed as managers. To restore an equilibrium, the demand for production labor also needs to increase. This increase occurs whenever the aggregate expenditure level $X$ rises.

Since both curves intersect once, there exists a unique equilibrium solution for $X$ and $s_{c}$. Setting both conditions equal gives a solution for the cutoff management skill $s_{c}$ and the aggregate expenditure level $X$ in the closed economy:

$$
X=\frac{\sigma L \lambda w}{\varepsilon(\sigma-1) \lambda+\psi} \quad s_{c}=1+\frac{\varepsilon(\sigma-1) \lambda}{\psi} .
$$

Given this aggregate expenditure level in the economy and the cutoff management skill level, the reservation wages for managers can be stated as follows:

$$
u(s)=\lambda w \frac{\mu}{\kappa+\mu}\left[\left(\frac{s}{s_{c}}\right)^{(\kappa+\mu)(\sigma-1)}-1\right]+w .
$$

Equation (12) illustrates that the compensation of a manager increases with his relative position to the marginal manager in the market. Since the level of compensation is increasing with management skills, firms will choose different levels of corporate governance investments to provide incentives. Managers with relatively high levels of management skills have relatively high reservation wages $u(s)$ since their impact on the profits that firms make is large. Consequently, the firms that compete for the managers with the highest management skills in the economy will invest less into corporate governance and incentivize their managers with a high performance compensation. In contrast to the largest firm in the economy, firms that employ managers at the lower end of the management skill distribution will invest into solid corporate governance to make sure that 
managers are appropriately incentivized.

I obtain the optimal level of corporate governance from plugging the equilibrium reservation wages into the optimal choice of corporate governance and get:

$$
g= \begin{cases}1+\frac{w}{b}-\frac{\lambda w \mu}{b(\kappa+\mu)}\left[\left(\frac{s}{s_{c}}\right)^{(\kappa+\mu)(\sigma-1)}-1\right] & \text { if } s \leq \widetilde{s} \\ 0 & \text { if } s>\widetilde{s}\end{cases}
$$

Firms that employ managers with a skill level above $\widetilde{s}$ do not invest into corporate governance and only rely on performance compensation to incentivize their managers. Managers with skills below $\widetilde{s}$ are incentivized with a combination of performance payments and corporate governance. This threshold skill level $\widetilde{s}$ is given by:

$$
\widetilde{s}=\left(1+\frac{(\kappa+\mu)(b-w)}{\lambda \mu w}\right)^{\frac{1}{1-\psi}} s_{c} .
$$

Note that $\widetilde{s}$ increases proportionally with the cutoff management skill $s_{c}$. A higher level of the cutoff management skill increases the degree of product market competition and therefore means ceteris paribus lower firm profits. Consequently, a higher cutoff management skill level $s_{c}$ puts downward pressure on the compensation of managers which leads to higher investments in corporate governance in the economy.

Another informative statistic that is immediately deductible from $\widetilde{s}$ and describes the state of corporate governance in the total economy is the fraction of firms that do not invest in corporate governance in equilibrium. This fraction of firms $\theta$ equals

$$
\theta \equiv \frac{L \widetilde{s}^{-1}}{L s_{c}^{-1}}=\left(1+\frac{(\kappa+\mu)(b-w)}{\lambda \mu w}\right)^{\frac{1}{\psi-1}}
$$

Intuitively, this fraction of firms $\theta$ is large when the costs of corporate governance $\lambda$ are relatively large or when managers have little private benefits from shirking $b$ and thus require only little work incentives. The following proposition summarizes how firms in the economy choose to provide incentives.

\section{Proposition 2.}

In a closed economy, there exists a threshold skill level $\widetilde{s}$.

A fraction $\theta$ of the largest firms in the economy competes for managers with skill levels $s>\widetilde{s}$. These firms do not invest into corporate governance and provide managerial incentives solely with performance compensation. 
The remaining firms that compete for managers with skill levels $s \leq \widetilde{s}$ incentivize managers with investments into corporate governance and performance compensation.

Proof. See Appendix.

\subsection{Technological Change and the Choice of Incentives}

How does technological change affect the way how firms set up incentives? This section illustrates the comparative statics of a technological change on the level of performance payments and firm investments into corporate governance in the described framework. There has been a debate in the economics literature that technological change is to a large extent skill-biased in the sense that it increases the effectiveness of technologies that disproportionally benefit the productivity of firms that employ relatively high-skilled agents. For instance, the availability of computers and related information technologies is particularly relevant for workers that frequently use these technologies. ${ }^{11}$

This skill-bias in technological change can be modeled as an exogenous increase in the parameter $\kappa$ which measures the influence of the production technology on the overall firm productivity. ${ }^{12}$ A higher value for $\kappa$ immediately translates into a more dispersed productivity distribution since the productivity of firms with higher skilled agents improves disproportionally. ${ }^{13}$ First, I consider the effects of skill-biased technological change on the zero cutoff earnings condition. Then, I analyze how the effects on $X$ and $s_{c}$ affect corporate governance investment decisions across firms and how this ultimately changes the share of firms $\theta$ that do not invest into corporate governance.

An increase in $\kappa$ changes the zero cutoff earnings condition (9) and leaves the labor market equilibrium clearing condition (10) unaffected since changes in the effectiveness of technologies neither affect the aggregate production labor expenditure nor the earnings on production labor. In order to understand how skill-biased technological change affects the zero earnings firm, note that a skill-biased increase in the effectiveness of technologies has two opposing effects on the surplus of this marginal firm. First, there is a positive productivity effect since the marginal costs $\frac{t^{\kappa} s_{c}^{\kappa+\mu}}{w}$ decrease. Second, there is a negative market size effect that is due to a lower price index because all other firms also become more productive. Since an increase in $\kappa$ disproportionally benefits firms that employ relatively high skilled agents, the negative effect on the price index dominates the positive productivity effect for the marginal firm. To restore zero earnings for a given cutoff skill

\footnotetext{
${ }^{11}$ See Autor et al. (1998) for empirical evidence.

${ }^{12}$ See Monte (2011) who studies the effects of an increase in $\kappa$ on the dispersion of wages.

${ }^{13}$ The elasticity of the firm productivity with respect to changes in $\kappa$ is increasing in the employed skill level $s$ since $e(\kappa)=\kappa \ln (t s)$.
} 
$s_{c}$, the marginal firm now requires a larger expenditure level $X$ to cover the corporate governance costs to enter the market. This mechanism turns the zero cutoff earnings curve outward which unambiguously increases $X$ and the cutoff skill $s_{c}$ in the new equilibrium.

This skill-biased technological change has three effects on the threshold skill level $\widetilde{s}$ from equation (14). First, an increase of $\kappa$ strengthens the contribution of the production technology to firm productivity and therefore weakens the bargaining position of the manager and decreases reservation wages of managers (the bargaining effect). This decrease of reservation wages translates to a lower share of weak governance firms in the economy since lower performance payments require additional incentives from stricter monitoring. Second, an increase of $\kappa$ increases the marginal productivity of managers and thus has a positive effect on reservation wages which reduces the threshold skill level $\widetilde{s}$ and increases the share of firms $\theta$ that do not invest into corporate governance (the productivity effect). Third, skill-biased technological change leads to a tougher selection among firms as the cutoff skill $s_{c}$ increases such that reservation wages fall and $\widetilde{s}$ increases (the selection effect). This selection effect only affects the threshold skill level $\widetilde{s}$ but leaves the share of organizations with zero corporate governance investments $\theta$ unaffected as $\widetilde{s}$ increases proportionally with $s_{c}$. Consequently, tougher selection from technological change affects the number of firms but leaves the share of firms with weak governance unaffected. Nevertheless, the bargaining effect and the productivity effect have an influence on $\theta$. To see this, I restate $\theta$ as follows:

$$
\theta=\left(\frac{\lambda \mu w}{\lambda \mu w+(\kappa+\mu)(b-w)}\right)^{\frac{1}{(\kappa+\mu)(\sigma-1)}}
$$

The bargaining effect is captured by an increase of the denominator $\lambda \mu w+(\kappa+\mu)(b-w)$ such that $\theta$ decreases. The positive productivity effect is captured by a decrease of the exponent $\frac{1}{(\kappa+\mu)(\sigma-1)}$ such that $\theta$ rises. I show in the appendix that the productivity effect outweighs the bargaining effect such that $\frac{\partial \theta}{\partial \kappa}>0$. The following proposition summarizes how skill-biased technological change in the economy affects firm decisions to provide incentives.

\section{Proposition 3.}

Technological change that is skill-biased $(\kappa \uparrow)$ increases competition for the relatively high skilled managers in an economy.

This leads to an increase in the fraction $\theta$ of firms that do not invest into corporate governance and provide managerial incentives solely with performance compensation.

Proof. See Appendix. 


\subsection{Open Economy}

The current section extends the model to an open economy version. I consider two symmetric countries that participate in intra-industry trade. Economic activities on the domestic market are denoted with a subscript $d$ and exporting activities with a subscript $x$. An exporting firm needs to produce $\tau>1$ units of a good for 1 unit to reach the foreign destination. Additionally, a firm needs to incur a fixed amount of production labor $f$ to sell to the export market. Formally, a firm that employs a manager with skill $s$ in the open economy setting faces the following objective function:

$$
\max \varepsilon\left(Y_{d}(s)+I_{x} Y_{x}(s)-r(s)\right)-I_{x} f w-g(s)((1-\varepsilon) l w-m w)
$$

where $I_{x}$ is an endogenous export participation indicator. Again, firms choose the performance compensation $r(s)$ and the level of corporate governance investment $g(s)$ according to proposition 1. Since exporting firms face identical demand elasticities on both markets, the exporting price is a constant multiplier of the domestic price adjusted by the variable trade cost: $p_{x}(s)=\tau p_{d}(s)$. Therefore, the operating profits from exporting are

$$
Y_{x}(s)=\tau^{1-\sigma} Y_{d}(s)=\tau^{1-\sigma} M\left(\frac{t^{\kappa} s^{\kappa+\mu}}{w}\right)^{\sigma-1} .
$$

Denote $s_{d}$ the management skill in the marginal domestic firm and $s_{x}$ the management skill in the marginal exporting firm. Firms will choose to export whenever their productivity is large enough to cover the fix costs of exporting. Thus, the marginal exporter obtains operating profits from exporting $Y_{x}\left(s_{x}\right)$ that are just sufficiently large to cover the fixed costs of entering the export markets such that $\varepsilon M\left(w^{-1} t^{\kappa} s_{x}^{\kappa+\mu}\right)^{\sigma-1}=\tau^{\sigma-1} \mathrm{fw}$. The management skill level of the marginal exporter $s_{x}$ can be written as a function of the marginal skill level of a domestic firm manager $s_{d}$

$$
s_{x}=\left(\frac{\tau^{\sigma-1} f}{\lambda}\right)^{\frac{1}{1-\psi}} s_{d}
$$

where I assume that $\left(\tau^{\sigma-1} f\right)^{\frac{1}{1-\psi}}>\lambda$ in order to make sure that there is any meaningful exporting behavior of firms with $s_{x}>s_{d} \cdot{ }^{14}$ The open economy price index can now be written as

$$
P=\frac{\sigma}{\sigma-1} w t^{-\kappa}\left(\frac{\psi}{\varepsilon L}\right)^{\frac{1}{\sigma-1}} s_{d}^{\frac{\psi}{\sigma-1}}\left[1+\lambda^{\frac{\psi}{1-\psi}} \Delta^{-1}\right]^{1 /(1-\sigma)}
$$

where $\Delta \equiv \tau^{\frac{1}{\kappa+\mu}} f^{\frac{\psi}{1-\psi}}$ is an index that captures the distance between both countries. The term $\left(1+\lambda^{\psi / 1-\psi} \Delta^{-1}\right)^{1 /(1-\sigma)}$ captures the effect of foreign competition on the price index.

\footnotetext{
${ }^{14}$ Otherwise, some firms would rather export than sell on the domestic market.
} 
If the economic distance between the two countries is small (low values for $\Delta$ occur whenever $f$ and $\tau$ are small), competition from foreign exporters lowers the domestic price index. In the limit, when both economies are very remote and $\Delta$ approaches infinity, the price index converges to its closed economy version. An equilibrium in the open economy again requires that the labor market clearing condition and the zero cutoff earnings condition are satisfied.

Consider the zero cutoff earnings condition in the open economy. The smallest domestic firm in the economy faces additional competition from foreign exporters through a lower price index (18). This yields the following open economy version of the zero cutoff earnings condition:

$$
X=\frac{\sigma L \lambda w}{\psi}\left[1+\lambda^{\frac{\psi}{1-\psi}} \Delta^{-1}\right] s_{d}^{-1} .
$$

For a given level of management skills $s_{d}$ the marginal domestic firm requires a higher expenditure level $X$ to survive in the market when the both countries become integrated more closely and $\Delta$ decreases. When the economic distance $\Delta$ approaches infinity, equation (19) resembles the closed economy case.

Also the labor market clearing condition changes in the open economy. The aggregate expenditure on production labor now consists of three components: besides the expenditure on production labor to produce output for the domestic market, there is expenditure on production labor to produce for the foreign market and additionally, expenditure on production labor that is required to cover the fixed investments $f$ to enter export markets. The aggregate expenditure on production labor can again be found by integrating the labor demand of an individual firm over all active firms and now includes the additional labor expenditure to cover the fix costs of exporting. Similar to the closed economy case, expenditure on production labor can be simplified to $\varepsilon X(\sigma-1) \sigma^{-1}+f w L s_{x}^{-1}$ such that the labor market clearing condition in the open economy is given by

$$
X=\frac{\sigma}{\sigma-1} \frac{L}{\varepsilon}\left[1-\left(1+\lambda^{\frac{1}{1-\psi}} \Delta^{-1}\right) s_{d}^{-1}\right] .
$$

Here again, the additional factor $\lambda^{\frac{1}{1-\psi}} \Delta^{-1}$ captures the additional labor demand for the exporting activities of firms. For a given skill level $s_{d}$ globalization reduces the aggregate expenditure level $X$ that is required to clear the labor market. This effect can be explained by the effect of a trade integration on the selection of firms into export markets. With lower trade costs, more firms select into export markets such that the expenditure on labor to cover the fix exporting costs rises and less workers are engaged for output production (for a fixed skill level $s_{d}$ ) such that $X$ is lower in the open economy for any value of $s_{d}$.

Equations (19) and (20) determine the equilibrium solution for $X$ and $s_{d}$ in the open 
economy:

$$
X=\frac{\sigma L \lambda w\left(1+\lambda^{\frac{\psi}{1-\psi}} \Delta^{-1}\right)}{\psi+\varepsilon \lambda(\sigma-1)+(\psi+\varepsilon(\sigma-1)) \lambda^{\frac{1}{1-\psi}} \Delta^{-1}} \quad s_{d}=1+\frac{\varepsilon \lambda(\sigma-1)}{\psi}+\left(1+\frac{\varepsilon(\sigma-1)}{\psi}\right) \lambda^{\frac{1}{1-\psi}} \Delta^{-1} .
$$

The equilibrium function of reservation wages in the open economy now requires a case distinction. Managers that are employed by exporting firms obtain an additional reservation wage premium $\varepsilon M\left(\frac{t^{\kappa}}{w}\right)^{\sigma-1} \frac{\mu}{\kappa+\mu} \tau^{1-\sigma}\left(s^{1-\psi}-s_{x}^{1-\psi}\right)$ that arises from serving a larger market. Trade opportunities allow them to additionally serve foreign markets such that these managers have a higher marginal productivity compared to the closed economy case:

$$
u(s)= \begin{cases}\varepsilon M\left(\frac{t^{\kappa}}{w}\right)^{\sigma-1} \frac{\mu}{\kappa+\mu}\left(s^{1-\psi}-s_{d}^{1-\psi}\right)+w & \text { if } s \in\left[s_{d}, s_{x}\right) \\ \varepsilon M\left(\frac{t^{\kappa}}{w}\right)^{\sigma-1} \frac{\mu}{\kappa+\mu}\left(\left(s^{1-\psi}-s_{d}^{1-\psi}\right)+\tau^{1-\sigma}\left(s^{1-\psi}-s_{x}^{1-\psi}\right)\right)+w & \text { if } s \geq s_{x} .\end{cases}
$$

It is straightforward to analyze the comparative static effects of a trade cost reduction on the choice of firms to set up incentives for managers.

\subsection{Trade Liberalization and the Choice of Incentives}

This section analyzes how a reduction of economic distance $\Delta$ between both countries affects the way how firms incentivize their managers. A reduction of economic distance $\Delta$ between both countries, either stemming from a decrease of the variable or the fix trade costs $d \tau<0$ or $d f<0$, has an effect on both, the labor market clearing and the zero cutoff firm condition. Figure 1 illustrates the effects of a trade integration on the domestic managerial cutoff skill level $s_{d}$. If the economies become more integrated, the labor market curve shifts downwards. Intuitively, better exporting opportunities allow the labor market to clear at a lower expenditure level. Simultaneously, closer integration shifts the zero cutoff earning curve upwards. A trade integration fosters import competition such that the marginal domestic producer requires a larger expenditure level to break even. These two effects lead to an unambiguous increase of the domestic managerial cutoff skill $s_{d}$. Furthermore, the cutoff skill of the marginal exporting firm $s_{x}$ falls since a lower productivity level is sufficient to cover the fix trade costs and a larger share of firms become exporters since $\partial\left[s_{d} / s_{x}\right] / \partial \Delta<0$.

Figure 1 about here

In the interest of a statement on the comparative statics of firm governance in an open economy, I distinguish two cases: first the case with low trade openness (large $\Delta$ ), then the 
case with high trade openness (small $\Delta$ ). The effect of a trade liberalization on reservation wages differ in those two cases which has different effects on the choice of incentives in equilibrium.

\section{Low Trade Openness}

Suppose that both countries are very remote such that the selection of firms into exporting is only efficient for a small share of firms. In this scenario, the export cutoff managerial skill level of the marginal exporter $s_{x}$ is very high such that the sorting of skill levels is as follows:

$$
s_{d}<\widetilde{s}<s_{x}
$$

Since only very few firms export, most managers cannot benefit from trade liberalization since these managers do not obtain an exporter wage premium. If the cutoff skill level $\widetilde{s}$ is smaller than the export cutoff skill level $s_{x}$, all exporters (and additionally some non-exporters) are weakly governed firms that do not invest into corporate governance. The cutoff $\widetilde{s}$ can again be evaluated as the skill level of the manager that has an outside option with value $b$ such that this manager is the least productive manager that is hired by a firm that chooses not to invest in corporate governance:

$$
\varepsilon M\left(\frac{t^{\kappa}}{w}\right)^{\sigma-1} \frac{\mu}{\kappa+\mu}\left(\widetilde{s}^{(\kappa+\mu)(\sigma-1)}-s_{d}^{(\kappa+\mu)(\sigma-1)}\right)+w=b .
$$

This leads to an equilibrium fraction of firms with zero corporate governance of

$$
\theta \equiv \frac{L \widetilde{s}^{-1}}{L s_{d}^{-1}}=\left(1+\frac{(\kappa+\mu)(b-w)}{\lambda \mu w}\right)^{\frac{1}{\psi-1}}
$$

which is identical as in closed economy version of the model. Obviously, $\theta$ is not affected by changes in the openness of the economies. In this scenario, economic integration only increases the reservation wages of the managers that are employed by the most productive exporting firms. Only these managers obtain an exporter wage premium that allows them to compensate the downward pressure on reservation wages arising from tougher import competition. The remaining managers suffer from tougher selection via an increase in $s_{d}$. Since $\widetilde{s}$ increases proportionally with $s_{d}$, the fraction of weak governance firms $\theta$ remains unaffected.

\section{High Trade Openness}

Next, suppose that both countries are relatively integrated such that sufficient firms serve the export market. In this scenario, the export cutoff management skill level $s_{x}$ is very 
low such that the sorting of skill levels is as follows:

$$
s_{d}<s_{x}<\widetilde{s}
$$

This sorting implies that the firm that employs the manager with the organizational cutoff skill $\widetilde{s}$ is an exporting firm. Consequently, the organizational cutoff $\widetilde{s}$ is defined as

$$
\varepsilon M\left(\frac{t^{\kappa}}{w}\right)^{\sigma-1} \frac{\mu}{\kappa+\mu}\left(\left(\widetilde{s}^{1-\psi}-s_{d}^{1-\psi}\right)+\tau^{1-\sigma}\left(\widetilde{s}^{1-\psi}-s_{x}^{1-\psi}\right)\right)+w=b
$$

which leads to the following term for the share of organizations with weak governance $\theta$ :

$$
\theta=\left(\left(\frac{(\kappa+\mu)(b-w)+\lambda \mu w}{\lambda \mu w}-\frac{\lambda}{\tau^{2(\sigma-1) f}}\right)\left(\frac{1}{1+\tau^{1-\sigma}}\right)\right)^{-\frac{1}{1-\psi}}
$$

Now, the fraction of firms with no investments into corporate governance depends on the degree of economic integration. A reduction in either the variable trade costs $\tau$ or the fix trade costs $f$ unambiguously increases the fraction $\theta$. Intuitively, a reduction of trade costs increases the reservation wages for a large fraction of the managers in the economy since these become more productive and firms that compete for management skills are willing to pay them more. Consequently, firms invest less into corporate governance and offer more performance compensation. The following proposition summarizes how economic integration through a reduction of trade costs affects firm decisions to provide incentives.

\section{Proposition 4.}

Consider a reduction in fix or variable trade costs in an open economy. This reduction in trade costs increases the reservation wages of the highest skilled managers in the economy which induces the largest firms to incentivize their managers with performance compensation instead of investing into corporate governance to monitor their managers.

If the open economy is sufficiently integrated such that $s_{d}<s_{x}<\widetilde{s}$ a reduction in fix or variable trade costs leads to an increase in the fraction $\theta$ of firms that do not invest into corporate governance and provide incentives solely with performance compensation.

Proof. See Appendix.

\section{Empirical Analysis}

This section investigates the comparative static predictions of the model from propositions 3 and 4 empirically, using variation in managerial entrenchment opportunities and equity compensation in large public industrial firms in the U.S. I begin with a brief description 
of the data sources and the variable construction, then describe the estimation strategy and conclude with a discussion of the evidence.

\subsection{Data}

The empirical analysis draws on firm level data from two main sources. In order to measure corporate governance quality at the firm level, I use the entrenchment index (E index) from Bebchuk et al. (2009). This index combines information on six governance provisions that capture managerial entrenchment opportunities and are associated with adverse managerial behavior inside firms. The E index is constructed by counting how many of the following six governance provisions are in place in a given firm-year: staggered boards, limits to shareholder bylaw amendments, poison pills, golden parachutes, and supermajority requirements for mergers as well as for charter amendments. Four of these six provisions are associated with limited voting power of shareholders (staggered boards, limits to shareholder bylaw amendments, supermajority requirements for mergers, supermajority requirements for charter amendments), while the two remaining provisions (poison pills and golden parachutes) are salient measures taken in preparation for hostile offers which can be used by the executive board to prevent an unpopular merger leading to their displacement. Bebchuk et al. (2009) argue that these six provisions are the most relevant ones since they play a key role in the relation between corporate governance and firm value. ${ }^{15}$ Information on the six different governance attributes is provided by the Investor Responsibility Research Center (IRRC) and includes S\&P 500 firms and a set of additional firms. I use the final $\mathrm{E}$ index score that ranges between 0 to 6 , based on the number of these provisions that a firm provides in a given year such that higher values correspond to more managerial entrenchment. Observations span the time period between 1990 and 2006 with gaps: there is information on the E index for the years 1990, 1993, 1995, 1998, 2000, 2002, 2004 and 2006. ${ }^{16}$

As the second main data source, I use information about executive compensation in quoted U.S. corporations that is provided by BoardEx. BoardEx is a commercial business intelligence service provider that collects remuneration details on business leaders across the world. BoardEx provides information on the direct part of remuneration including fixed compensation and performance payments. Furthermore, BoardEx intends to measure equity-linked compensation. The equity-linked compensation measure includes the total

\footnotetext{
${ }^{15}$ These six provisions are also a subset of the GIM corporate governance index by Gompers et al. (2003). However, while the GIM index captures governance practices in various areas of the organization, the E index focuses on measuring governance practices related to adverse behavior of executive boards. Therefore, the E index is a more direct proxy for the firms' strength in monitoring managers.

${ }^{16}$ The E-index panel data are publicly available on Lucian Bebchuk's website http://www.law. harvard.edu/faculty/bebchuk/data. shtml.
} 
value of awarded shares, the estimated value of awarded options ${ }^{17}$ and long-term incentive plans (LTIPs) within a year. Since the company was registered only in 1999, the BoardEx compensation panel data start in $1998 .^{18}$

I match the entrenchment and the equity compensation panels with firm level balance sheet information from Thomson Reuters Worldscope. Worldscope provides balance sheet information and the main 4-digit SIC industry where each company is active in.

The industry level data that are used in the empirical analysis are obtained from three different sources. First, I use the NBER CES manufacturing industry database to obtain information on total factor productivity and value of shipments at the SIC 4-digit industry level. Additionally, I use the UN Comtrade database to obtain U.S. trade flows (exports and imports) at the SIC 4-digit level. My sectoral measures of trade openness build on those two data sources. In order to capture changes in the effective market size at the sectoral level; I divide exports by "domestic market size" (total value of domestic shipments plus imports) at the SIC 4-digit level. Since this measure of export openness is very dispersed across industries and also over time, I winsorize the sectoral trade measure by taking natural logarithms. In order to capture the role of I.T. at the industry level, I use the share of I.T. capital in total capital formation from the EUKLEMS database. ${ }^{19}$ The Data Appendix provides summary statistics of all variables and more detailed information about the construction of the data.

\subsection{Empirical Modeling}

My theoretical model indicates that large firms increase performance compensation and reduce their investments into corporate governance when their industries become more open to trade or when skill-biased technological change occurs. The rise in trade openness and the I.T. revolution where two developments during the 1990s and early 2000s that vastly changed the market environment faced by U.S. firms. Figure 2 illustrates the rise in trade and information technologies in U.S. manufacturing between 1990 and $2006{ }^{20}$ The left panel (a) shows an increase of the average exports relative to the value of domestic shipments per 4-digit SIC manufacturing industry in the U.S. The right panel (b) plots

\footnotetext{
${ }^{17}$ Option values are based on a generalized Black-Scholes option pricing model using the latest closing stock price; volatility is measured using a 100-day historic volatility; if option price expiry dates were unavailable, BoardEx uses the U.S. average remaining period.

${ }^{18}$ Since BoardEx data are mostly formatted for business client applications, a preparation of the data for academic purposes was needed before the data could be used for empirical work. Please see the Data Appendix for more details on the necessary preparation steps and underlying assumptions.

${ }^{19}$ Data from EUKLEMS have also been used by Michaels et al. (2014) to estimate whether ICT has polarized the demand for skilled labor.

${ }^{20}$ The data sources are the UN Comtrade database for industry exports, the EUKLEMS database for the share of I.T. capital and the NBER CES manufacturing industry database for domestic shipments.
} 
the rise in I.T. capital relative to the total capital stock per 4-digit SIC manufacturing industry in the U.S.

Figure 2 about here

Based on the two model propositions 3 and 4, I formulate the following testable prediction.

\section{Empirical Prediction.}

Firms allow for more managerial entrenchment and offer larger CEO compensation when their industries are more open to trade or when production is more I.T. intensive.

In order to analyze how shareholders adjust incentives either via the arrangement of corporate governance provisions which can facilitate or impede adverse managerial behavior or via changes in executive compensation, I estimate empirical models of the following type:

$$
Y_{f j t}=\beta_{1} T R A D E_{j t}+\beta_{2} I T_{j t}+X_{f j t}^{\prime} \delta+\eta_{f}+\eta_{t}+u_{f j t},
$$

where $Y_{f j t}$ stands for the dependent variables entrenchment index or alternatively, for the level of CEO compensation in a firm $f$ that is active in industry $j$ during period $t$. The main regressors of interest are the export openness $T R A D E_{j t}$ and the I.T. investment intensity of the industry $I T_{j t}$. Specifically, the variable $T R A D E_{j t}$ is the natural logarithm of exports divided by domestic shipments plus imports within a SIC 4-digit industry. The variable $I T_{j t}$ is the share of I.T. capital investments divided by the total capital formation of the industry. Information on I.T. investments is obtained from EUKLEMS. Since EUKLEMS data are aggregated at the 2-digit NACE level, I match each firm into its corresponding NACE industry. Furthermore, the vector $X_{f j t}$ is a set of control variables. In all regressions, I additionally control for industry total factor productivity, proxied by the 4-factor TFP index obtained from the NBER CES manufacturing database, firm labor productivity as well as firm size measured by total assets. When estimating models for CEO compensation, I additionally include stock investment returns as a control. Since there may be many unobservables that are broadly constant over the sample period but correlated with governance provisions or executive compensation at the firm level and trade or I.T. at the industry level, I include a firm fix effect $\eta_{f}$. This firm fix effect controls for any time invariant unobservable at the firm or industry level. Moreover, all estimations include a set of year dummies $\eta_{t}$ to control for unobservable macroeconomic shocks.

Furthermore, in order to identify the effects of trade shocks on managerial entrenchment and CEO compensation, I follow an instrumentation strategy. My two instruments for the export openness within an industry are an industry specific basket of real effective 
exchange rates and the maritime transportation costs for container trade from the U.S. to Europe. The real effective exchange rate instrument is an industry specific basket of the real effective exchange rate indices from Canada, China, Japan, Mexico and the United Kingdom vis-à-vis the rest of the world. These five countries are the main U.S. trading partners and I weight each of the five indices according to the SIC 4-digit specific average import shares between 1991 - 1995. Maritime transport costs are obtained from the OECD and measure the ad valorem transport costs for container trade from the U.S. to the European Union at the HS-1998 6-digit product level. Here, I merge the product level data to SIC 4-digit industries. I refer to the Data Appendix for a more detailed description of the instrumental variables. While the exchange rate instrument captures changes in comparative advantages over time, the ad valorem maritime transport costs are a proxy for iceberg type trade costs.

\subsection{Results}

Table 1 shows results for regressions of the entrenchment index on the industry measures of export openness and I.T. intensity. Generally, the estimates suggest that higher levels of industry export openness and I.T. investments are associated with higher levels of managerial entrenchment. In the OLS regressions in columns (1) and (2), both coefficients for export openness and IT investments are significant at the $5 \%$ level. A problem with estimating these equations is the endogeneity of industry trade and information technology due to reversed causality or unobserved shocks at the industry level that are correlated with managerial entrenchment and explanatory variables. In order to identify the effect of a trade shock on managerial entrenchment, I instrument export openness with the exchange rate basket and maritime transport costs. The correlation of the instruments is meaningful in the sense that appreciations of the foreign currencies and reductions in transport costs from the U.S. to Europe lead to more exports by U.S. industries. The preferred specification is presented in column (3), where both instruments are used. The Angrist-Pischke $F$-statistic to test for weak identification is 5.99 which rejects the null hypothesis of a weakly identified model for a maximum bias of $30 \%$ IV size. The $p$-value of the Hansen $J$-statistic to test for overidentification is 0.94 and thus, the null hypothesis of an overidentified model is not rejected. The parameter estimate for the export openness effect of 0.542 suggests that a one within firm standard deviation increase of export openness from its mean increases the entrenchment index by 0.13 points which is about $25 \%$ of the within firm standard deviation of the entrenchment index. The estimate of the I.T. investment effect of 5.386 suggests that a one within firm standard deviation of the I.T. investment measure increases the entrenchment index by 0.09 points. Thus, the estimates support the model prediction that large public firms allowed for more managerial 
entrenchment when their industries became more open and more I.T. intensive.

Next, consider the effect of trade and I.T. on CEO compensation. Table 2 shows results for regressions that analyze the association between CEO compensation and the industry measures of export openness and I.T. intensity. The specifications of the estimations include the same control variables from the previous models and I additionally include the total investment return (i.e. the stock return corrected for any dividend payments and stock splits) to control for variation in firm performance. The estimates suggest that executive compensation, both in total amounts and the equity linked parts, are positively associated with industry export openness and I.T. investments. Notably, the correlation between industry exports and the maritime transport cost instrument is very small compared to those in Table 1 . The reason lies in the variation of the transport cost variable over time: while transport costs decreased until 2000, they remained fairly flat since 2000. ${ }^{21}$ Since the BoardEx sample begins in 1998, maritime transport costs do not seem to be the most determining factor for export openness. Consequently, my preferred IV specification uses variation in real effective exchange rates as the instrument and is presented in column (3) for total CEO compensation and in column (5) for the equity-linked part of CEO compensation. Here, the Angrist-Pischke $F$-statistics for weak identification are 5.66 (3), respectively 6.33 (5). The estimated coefficients for export openness suggest an elasticity of total CEO payments to export openness of 2.55 and an equity-linked compensation elasticity to export openness of 2.72. Moreover, a higher I.T. investment intensity is associated with higher CEO compensation. Overall, these estimates also support the model prediction that large public firms offered higher CEO compensation when their industries became more open and more I.T. intensive.

\section{Conclusion}

This paper analyzes how the creation of incentives with performance compensation and control is affected by changes in firms' market environment. To study this question, I integrate a stylized model of performance compensation and corporate governance investments into a general equilibrium model with heterogeneous firms and human capital. Since technologies and management skills are complementary in terms of firm productivity, a positive assortative assignment of skills to technologies arises in equilibrium. The most productive firms endogenously choose an organization where governance is weak and managers can extract rents because investments into stronger corporate governance

\footnotetext{
${ }^{21}$ See Figure 4 in the Data Appendix for a plot of the mean maritime transport costs across industries over time. Furthermore, a regression of export openness on transport costs and a dummy variable that equals 1 after the year 1998 shows that the negative association between transport costs and U.S. exports diminishes significantly after 1998.
} 
become inefficient incentive mechanisms when firms are constraint to pay high wages to compete for managerial talent.

The model relates to a puzzle in the development of CEO compensation: while incentive compensation has become more and more prominent over time, incentive provision via better control inside the firm has fallen behind. This pattern can be explained by changes in the firms' market environment through globalization or technological change. Trade liberalizations and skill-biased technological change toughen the competition for managerial talent and thereby induce firms to allow for more managerial entrenchment on average.

I analyze this prediction empirically with data on managerial entrenchment opportunities and CEO compensation in large public industrial companies in the U.S. and find positive effects of sectoral openness and the contribution of I.T. on managerial entrenchment inside firms and the compensation of managers. 
Table 1: Managerial Entrenchment, Export Openness, and I.T. Investments

\begin{tabular}{|c|c|c|c|c|c|}
\hline & (1) & (2) & (3) & (4) & (5) \\
\hline Method & OLS & OLS & IV & IV & IV \\
\hline Dependent Variable & Entrenchment Index & Entrenchment Index & Entrenchment Index & Entrenchment Index & Entrenchment Index \\
\hline Ln Export Openness & $\begin{array}{l}0.104^{* *} \\
(0.0513)\end{array}$ & $\begin{array}{l}0.107^{* *} \\
(0.0520)\end{array}$ & $\begin{array}{c}0.542^{* *} \\
(0.226)\end{array}$ & $\begin{array}{c}0.980 \\
(0.681)\end{array}$ & $\begin{array}{c}0.527^{* * *} \\
(0.183)\end{array}$ \\
\hline IT Investment Intensity & & $\begin{array}{l}4.121^{* *} \\
(1.941)\end{array}$ & $\begin{array}{c}5.386^{* * *} \\
(1.980)\end{array}$ & $\begin{array}{l}4.985^{* *} \\
(2.314)\end{array}$ & $\begin{array}{c}5.350^{* * *} \\
(2.022)\end{array}$ \\
\hline \multicolumn{6}{|l|}{ First Stage: } \\
\hline Real Effective Exchange Rates & & & $\begin{array}{c}0.0054^{* *} \\
(0.0026)\end{array}$ & $\begin{array}{c}0.0062^{* *} \\
(0.0029)\end{array}$ & \\
\hline Maritime Transport Costs & & & $\begin{array}{c}-0.817^{* * *} \\
(0.312)\end{array}$ & & $\begin{array}{c}-0.787^{* *} \\
(0.307)\end{array}$ \\
\hline Fix Effects & Firm, Year & Firm, Year & Firm, Year & Firm, Year & Firm, Year \\
\hline Observations & 3,898 & 3,898 & 3,591 & 3,748 & 3,591 \\
\hline Number of Firms & 980 & 980 & 802 & 830 & 802 \\
\hline Sample Period & 1993-2006 & $1993-2006$ & 1993-2006 & 1993-2006 & 1993-2006 \\
\hline R-squared & 0.090 & 0.092 & - & - & - \\
\hline
\end{tabular}

Notes: The dependent variable is the entrenchment index of firm $f$ in industry $j$ in year $t$ that ranges from 0 (good governance) to 6 (many entrenchment opportunities). The main regressors ln export openness and IT investment intensity, are the natural logarithm of exports relative to domestic shipments plus imports and the share of I.T. investments in total capital formation in industry $j$ and year $t$, respectively. All estimations additionally control for 4-factor TFP at the industry level (SIC 4-digit level, from NBER), firm labor productivity and total firm assets, all in natural logarithms. Angrist and Pischke F-statistics are 5.99 (3), 4.73 (4) and 6.59 (5). The p-value for the overidentification test (Hansen J-statistic) in specification (3) is 0.94. Standard errors in parentheses and robust to clustering at the industry level (SIC 4-digit level). ***, **, * denote 1, 5, 10\% significance. 
Table 2: Executive Compensation, Export Openness, and I.T. Investments

\begin{tabular}{|c|c|c|c|c|c|}
\hline & $(1)$ & $(2)$ & $(3)$ & (4) & $(5)$ \\
\hline Method & OLS & IV & IV & IV & IV \\
\hline Dependent Variable & Ln CEO Total Pay & Ln CEO Total Pay & Ln CEO Total Pay & Ln CEO Equity Pay & Ln CEO Equity Pay \\
\hline Ln Export Openness & $\begin{array}{l}-0.0717 \\
(0.0878)\end{array}$ & $\begin{array}{l}3.133^{*} \\
(1.801)\end{array}$ & $\begin{array}{c}2.550^{* *} \\
(1.257)\end{array}$ & $\begin{array}{c}3.156 \\
(2.067)\end{array}$ & $\begin{array}{l}2.723^{*} \\
(1.509)\end{array}$ \\
\hline IT Investment Intensity & $\begin{array}{c}24.42^{* * *} \\
(8.150)\end{array}$ & $\begin{array}{c}68.91^{* *} \\
(28.19)\end{array}$ & $\begin{array}{c}57.83^{* * *} \\
(21.00)\end{array}$ & $\begin{array}{l}84.35^{* *} \\
(35.72)\end{array}$ & $\begin{array}{c}74.25^{* * *} \\
(27.17)\end{array}$ \\
\hline \multicolumn{6}{|l|}{ First Stage: } \\
\hline Real Effective Exchange Rates & & $\begin{array}{c}0.0054^{* *} \\
(0.0027)\end{array}$ & $\begin{array}{c}0.0069^{* *} \\
(0.0029)\end{array}$ & $\begin{array}{c}0.0058^{* *} \\
(0.0027)\end{array}$ & $\begin{array}{c}0.0072^{* *} \\
(0.0029)\end{array}$ \\
\hline Maritime Transport Costs & & $\begin{array}{c}0.0024 \\
(0.0051)\end{array}$ & & $\begin{array}{c}0.0027 \\
(0.0046)\end{array}$ & \\
\hline Fix Effects & Firm, Year & Firm, Year & Firm, Year & Firm, Year & Firm, Year \\
\hline Observations & 4,702 & 4,579 & 4,694 & 4,234 & 4,340 \\
\hline Number of Firms & 671 & 649 & 663 & 637 & 650 \\
\hline Sample Period & 1998-2006 & 1998-2006 & 1998-2006 & 1998-2006 & 1998-2006 \\
\hline R-squared & 0.084 & - & - & - & - \\
\hline
\end{tabular}

Notes: The dependent variable is the natural logarithm of CEO total pay or equity compensation in firm $f$ in industry $j$ in year $t$. The main regressors ln export openness and IT investment intensity, are the natural logarithm of exports relative to domestic shipments plus imports and the share of I.T. investments in total capital formation in industry $j$ and year $t$, respectively. All estimations additionally control for 4 -factor TFP at the industry level (SIC 4-digit level, from NBER), firm labor productivity, total firm assets, all in natural logarithms, as well as stock returns. Angrist and Pischke F-statistics are 2.39 (2), $5.66(3), 2.89$ (4) and 6.33 (5). The p-value for the overidentification test (Hansen J-statistic) are $0.16(2)$ and $0.21(4)$. Standard errors in parentheses and robust to clustering at the industry level (SIC 4-digit level). ***, **, * denote 1, 5, 10\% significance. 


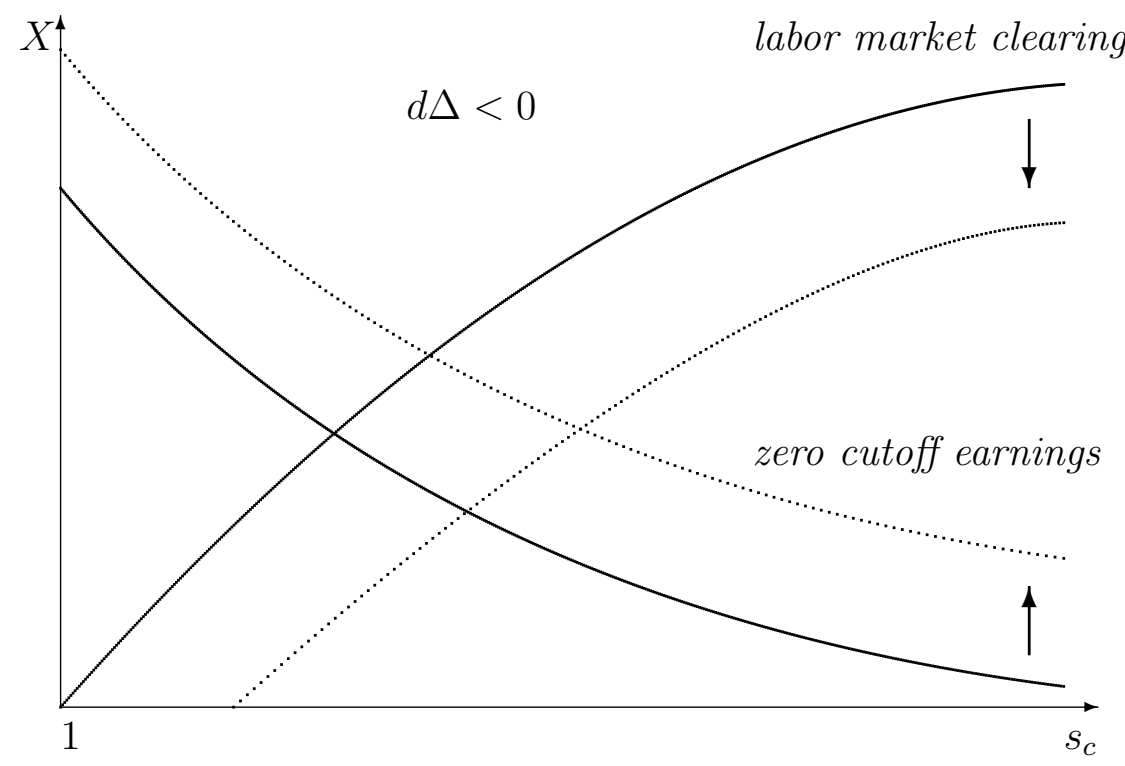

Figure 1: The effects of a trade integration $(d \tau<0$ and/or $d f<0)$ on the $s_{d}$.

(a)

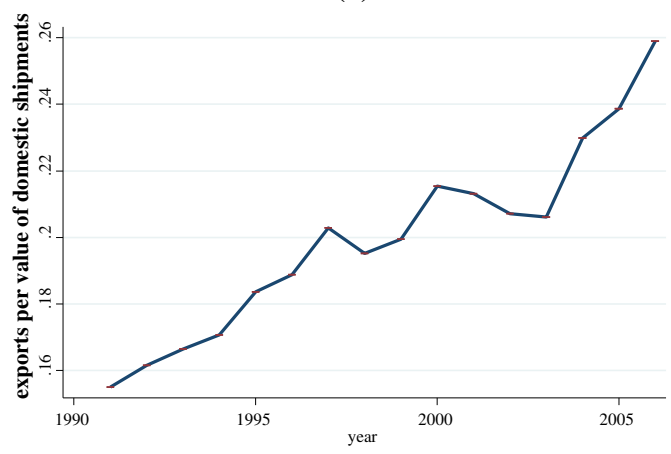

(b)

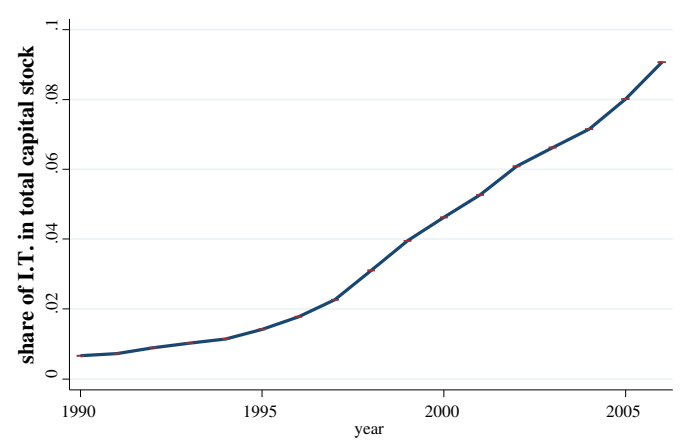

Figure 2: The increase in trade and information technologies in U.S. manufacturing industries between 1990 - 2006 . 


\section{References}

Acemoglu, Daron, Philippe Aghion, Claire Lelarge, John Van Reenen, and Fabrizio Zilibotti. Technology, Information, and the Decentralization of the Firm. Quarterly Journal of Economics, 122(4):1759-1799, 2007.

Acemoglu, Daron and Andrew Newman. The Labor Market and Corporate Structure. European Economic Review, 46(10):1733-1756, 2002.

Acharya, Viral, Marc Gabarro, and Paolo Volpin. Competition for Managers, Corporate Governance and Incentive Compensation. mimeo, New York University, 2013.

Aghion, Philippe and Jean Tirole. Formal and Real Authority in Organizations. Journal of Political Economy, 105(1):1-29, 1997.

Autor, David H., Lawrence F. Katz, and Alan B. Krueger. Computing Inequality: Have Computers Changed The Labor Market? Quarterly Journal of Economics, 113(4):1169-1213, 1998.

Baldwin, Robert E. and Glen G. Cain. Shifts In Relative U.S. Wages: The Role Of Trade, Technology, And Factor Endowments. Review of Economics and Statistics, 82(4):580-595, 2000 .

Baranchuk, Nina, Glenn MacDonald, and Jun Yang. The Economics of Super Managers. Review of Financial Studies, 24(10):3321-3368, 2011.

Bebchuk, Lucian, Alma Cohen, and Allen Ferrell. What Matters in Corporate Governance? Review of Financial Studies, 22(2):783-827, 2009.

Bebchuk, Lucian Arye and Jesse M. Fried. Executive Compensation as an Agency Problem. Journal of Economic Perspectives, 17(3):71-92, 2003.

Bell, Brian D. and John Van Reenen. Extreme Wage Inequality: Pay at the Very Top. American Economic Review, 103(3):153-57, 2013.

Bénabou, Roland and Jean Tirole. Bonus Culture: Competitive Pay, Screening, and Multitasking. CEPR Discussion Papers 9419, CEPR, 2013.

Bloom, Nicholas, Raffaella Sadun, and John Van Reenen. Does Product Market Competition Lead Firms to Decentralize? American Economic Review, 100(2):434-38, 2010.

Caliendo, Lorenzo and Esteban Rossi-Hansberg. The Impact of Trade on Organization and Productivity. Quarterly Journal of Economics, 127(3):1393-1467, 2012.

Chen, Cheng. The Agency Problem, Trade Liberalization and Within-Firm Productivity Gains: Theory and Evidence. mimeo, University of Hong Kong, 2014. 
Cuñat, Vicente and Maria Guadalupe. How Does Product Market Competition Shape Incentive Contracts? Journal of the European Economic Association, 3(5):1058-1082, 2005.

Cuñat, Vicente and Maria Guadalupe. Globalization and the Provision of Incentives inside the Firm: The Effect of Foreign Competition. Journal of Labor Economics, 27(2):179-212, 2009 .

Dicks, David L. Executive Compensation and the Role for Corporate Governance Regulation. Review of Financial Studies, 25(6):1971-2004, 2012.

Edmans, Alex, Xavier Gabaix, and Augustin Landier. A Multiplicative Model of Optimal CEO Incentives in Market Equilibrium. Review of Financial Studies, 22(12):4881-4917, 2009.

Eisfeldt, Andrea L. and Camelia M. Kuhnen. CEO Turnover in a Competitive Assignment Framework. Journal of Financial Economics, 109(2):351-372, 2013.

Falato, Antonio and Dalida Kadyrzhanova. Optimal CEO Incentives and Industry Dynamics. Finance and Economics Series 2012-78, Federal Reserve System, 2012.

Frydman, Carola and Dirk Jenter. CEO Compensation. Annual Review of Financial Economics, 2(1):75-102, 2010.

Gabaix, Xavier and Augustin Landier. Why Has CEO Pay Increased So Much? Quarterly Journal of Economics, 123(1):49-100, 2008.

Gersbach, Hans and Armin Schmutzler. Does Globalization Create Superstars? A Simple Theory of Managerial Wages. European Economic Review, 71(C):34-51, 2014.

Gompers, Paul, Joy Ishii, and Andrew Metrick. Corporate Governance and Equity Prices. Quarterly Journal of Economics, 118(1):107-155, 2003.

Guadalupe, Maria and Julie Wulf. The Flattening Firm and Product Market Competition: The Effect of Trade Liberalization on Corporate Hierarchies. American Economic Journal: Applied Economics, 2(4):105-27, 2010.

Korinek, Jane. Clarifying Trade Costs in Maritime Transport. OECD Working Papers, OECD, 2011.

Marin, Dalia, Jan Schymik, and Alexander Tarasov. Trade in Tasks and the Organization of Firms. CEPR Discussion Papers 10626, C.E.P.R., 2015.

Marin, Dalia and Thierry Verdier. Power Inside The Firm and The Market: A General Equilibrium Approach. Journal of the European Economic Association, 6(4):752-788, 2008.

Marin, Dalia and Thierry Verdier. Globalization and the Empowerment of Talent. Journal of International Economics, 86(2):209-223, 2012. 
Marin, Dalia and Thierry Verdier. Corporate Hierarchies and International Trade: Theory and Evidence. Journal of International Economics, 94(2):295-310, 2014.

Melitz, Marc J. The Impact of Trade on Intra-Industry Reallocations and Aggregate Industry Productivity. Econometrica, 71(6):1695-1725, 2003.

Michaels, Guy, Ashwini Natraj, and John Van Reenen. Has ICT Polarized Skill Demand? Evidence from Eleven Countries over Twenty-Five Years. Review of Economics and Statistics, 96(1):60-77, 2014.

Monte, Ferdinando. Skill Bias, Trade, and Wage Dispersion. Journal of International Economics, 83(2):202-218, 2011.

Terviö, Marko. The Difference That CEOs Make: An Assignment Model Approach. American Economic Review, 98(3):642-668, 2008.

Wu, Yanhui. Managerial Incentives and Compensation in a Global Market. CEP Discussion Papers 1066, Centre for Economic Performance, LSE, 2011. 


\section{APPENDIX}

\section{Theory Appendix}

\section{Proof of Proposition 1}

To ease the notation, I will drop the function argument $\cdot(s)$ throughout the proof. The owner's problem is given as follows:

$$
\begin{gathered}
\max _{r, g} \varepsilon(Y-r)+(1-\varepsilon) l w g-m w g \\
\text { s.t. } \\
\varepsilon r \geq(1-g) b \\
\varepsilon r \geq u
\end{gathered}
$$

with $m w \in((1-\varepsilon) l w,(1-\varepsilon) l w+b)$. This assumption ensures that the choice of $g$ is nontrivial. Governance would be always $g=1$ if $m w<(1-\varepsilon) l w$ and $g=0$ if $m w>(1-\varepsilon) m w+b$.

To find the optimal contract, the following case distinction is necessary:

Case i) $u>b$ : in that case the incentive constraint is slack whenever the participation constraint is satisfied. Consequently, the incentive constraint may be neglected and the agent receives a performance payment $r=u / \varepsilon$. Since incentives do not matter and to save on governance costs, the owner leaves all the power to shirk to the manager and chooses $g=0($ since $(1-\varepsilon) l w-m w<0)$.

Case $i$ i) $u \leq b$ : This case is somewhat less trivial since here it depends on the level of governance $g$ which constraint will bind. More governance increases the expected liquidation value $((1-\varepsilon) l w g)$ and rises monitoring costs $(m w g)$. Since $m w>(1-\varepsilon) l w$, more governance is costly for the owner. Nevertheless, there is a positive effect of governance: stricter governance creates incentives for the agent to exert effort. Suppose that the owner sets governance so weak such that $g<1-u / b$. Then, the incentive constraint would require that $r \geq(1-g) b / \varepsilon$. Thus, it is inefficient to reduce governance because it requires a relatively stronger increase in performance pay $r$. Next, suppose that $g>1-u / b$ such that only the participation constraint binds. Since governance bears a cost for the owner, she can improve by reducing $g$ such that both constraints are still satisfied. 


\section{Proof of Proposition 2}

\section{Derivation of the Equilibrium}

The derivation of the equilibrium is similar to Monte (2011). Consider first the zero cutoff earnings condition. The net earnings of the least productive firm that is active in the economy need to be zero such that:

$$
\varepsilon\left[M\left(\frac{t^{\kappa} s_{c}^{\kappa+\mu}}{w}\right)^{\sigma-1}-\frac{w}{\varepsilon}\right]-\left(1-\frac{w}{b}\right)(m-(1-\varepsilon) l) w=0 .
$$

The earnings of this marginal firm depend on its management skills $s_{c}$ and the market size $M \equiv \frac{1}{\sigma}\left(\frac{\sigma}{\sigma-1}\right)^{1-\sigma} X P^{\sigma-1}$. The market size $M$ depends itself on the economy price index $P$ which again depends on the cutoff skill level $s_{c}$. In order to resolve this issue, I resolve $M$ and state it in terms of the aggregate expenditure $X$ and the cutoff skill level $s_{c}$.

To solve for the price index and to save on notation, I define the term $\psi \equiv 1-(\sigma-1)(\kappa+\mu)$ which needs to be positive such that the price index exists. Intuitively, this means that the price index cannot be pushed towards zero by an individual firm. The C.E.S. price index can now be written as a function of fundamentals and the management skill $s_{c}$ itself. I obtain the price index from integrating over all prices that firms across the managerial skill distribution offer, using $z_{c}=t s_{c}$ for the marginal firm:

$$
\begin{aligned}
P & =\left[\int_{s_{c}}^{\infty}\left(\frac{\sigma}{\sigma-1} w t^{-\kappa} s^{-(\kappa+\mu)}\right){ }^{1-\sigma} d \varepsilon L\left(1-s^{-1}\right)\right]^{1 /(1-\sigma)} \\
& =\frac{\sigma}{\sigma-1} t^{-\kappa} w\left(\frac{\psi}{\varepsilon L}\right)^{1 /(\sigma-1)} s_{c}^{\psi /(\sigma-1)}
\end{aligned}
$$

Plugging the price index and the expenditure level $X$ into equation (26) and rearranging terms yields the zero cutoff earnings condition $X\left(s_{c}\right)$ :

$$
X=\frac{\sigma L w \lambda}{\psi} s_{c}^{-1}
$$

where $\lambda \equiv((1-w / b)(m-(1-\varepsilon) l)+1)$.

Consider next the labor market clearing condition. The supply of production labor is variable since it depends on the number of firms and therefore on the mass of agents that will be employed as managers. However, the labor market clears if the aggregate expenditure on production workers to produce the aggregate output is equal to the aggregate earnings 
of those production workers:

$$
\int_{s_{c}}^{\infty} \varepsilon(x(i)-Y(i)) L i^{-2} d i=L w\left(1-s_{c}^{-1}\right) .
$$

The left hand side of equation (28) integrates the difference between expected revenues and the expected surplus over all firms and thus corresponds to the aggregate expenditure on production labor in the economy. The right hand side corresponds to the aggregate earnings of production workers. A firm uses $1 / \varphi_{j}$ units of labor per unit of output and produces $q_{j}$ units of output with probability $\varepsilon$. The demand for production labor of an individual firm can be written in terms of prices since $q_{j}=x_{j} / p_{j}=X P^{\sigma-1} p_{j}^{-\sigma}$ and $1 / \varphi_{j}=\frac{\sigma-1}{\sigma} p_{j}$. Demand for production labor is thus given by

$$
\varepsilon \frac{q_{j}}{\varphi_{j}}=\varepsilon\left(\frac{\sigma-1}{\sigma} X P^{\sigma-1} p_{j}^{1-\sigma}\right)
$$

Integrating the production labor demand for the individual firm over all active firms of the economy yields

$$
\begin{aligned}
\int_{0}^{L s_{c}^{-1}}\left[\varepsilon \frac{\sigma-1}{\sigma} X P^{\sigma-1} p_{j}^{1-\sigma}\right] d j & =\varepsilon \frac{\sigma-1}{\sigma} X P^{\sigma-1} \int_{0}^{L s_{c}^{-1}} p_{j}^{1-\sigma} d j \\
& =\varepsilon \frac{\sigma-1}{\sigma} X
\end{aligned}
$$

Setting this expression equal to the aggregate supply from above gives the labor market clearing condition. This simplifies the labor market clearing condition to the following function $X\left(s_{c}\right)$ :

$$
X=\frac{L w}{\varepsilon} \frac{\sigma}{\sigma-1}\left(1-s_{c}^{-1}\right) .
$$

Figure 3 illustrates the zero cutoff earnings condition and the labor market clearing condition graphically. Solving for the cutoff management skill level $s_{c}$ by setting the two conditions equal yields

$$
\frac{L}{\varepsilon} \frac{\sigma}{\sigma-1} w\left(1-s_{c}^{-1}\right)=\frac{\sigma L \lambda w}{\psi} s_{c}^{-1} \Leftrightarrow s_{c}=1+\frac{\varepsilon(\sigma-1) \lambda}{\psi} .
$$

Solving for the expenditure level $X$ by plugging the solution for $s_{c}$ into the labor market clearing condition yields

$$
X=\frac{L}{\varepsilon} \frac{\sigma}{\sigma-1} w\left[1-\left(1+\frac{\varepsilon(\sigma-1) \lambda}{\psi}\right)^{-1}\right] \quad \Leftrightarrow \quad X=\frac{\sigma L \lambda w}{\varepsilon(\sigma-1) \lambda+\psi}
$$




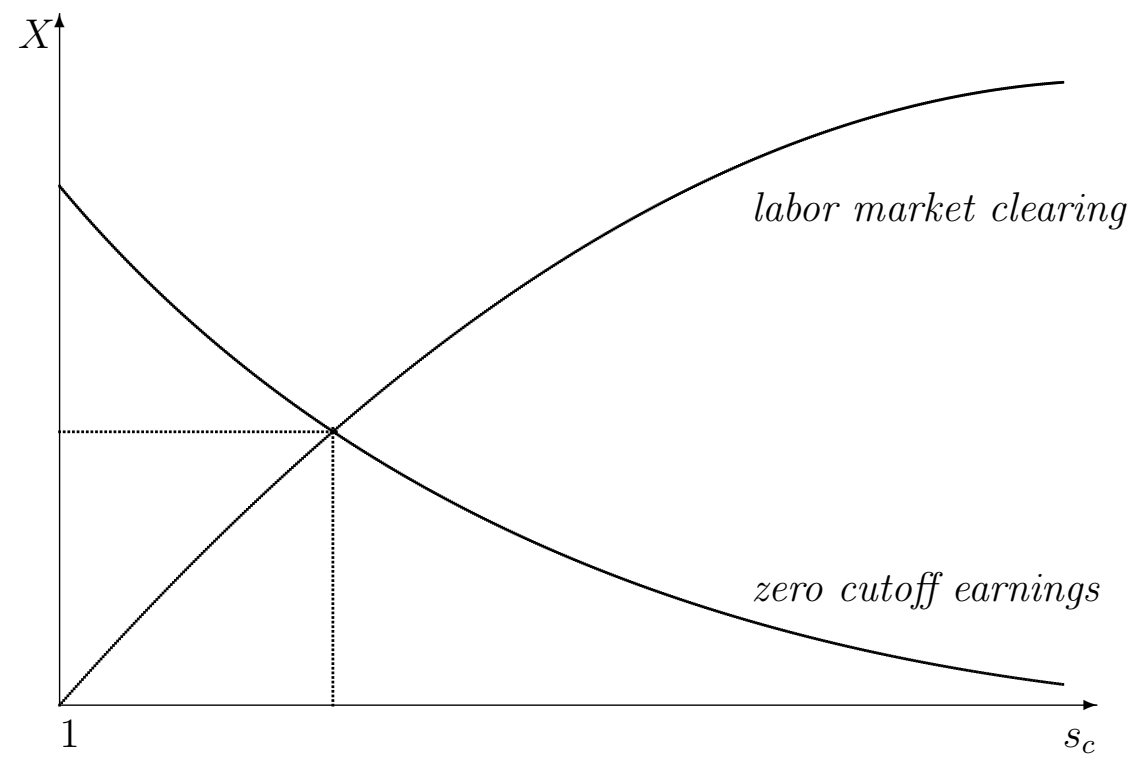

Figure 3: Determination of the closed economy equilibrium in the $\left(X, s_{c}\right)$ locus.

The equilibrium market size $M$ of a firm can now be stated as follows:

$$
M \equiv \frac{1}{\sigma}\left(\frac{\sigma}{\sigma-1}\right)^{1-\sigma} X P^{\sigma-1}=\frac{\lambda}{\varepsilon} w^{\sigma} t^{-\kappa(\sigma-1)} s_{c}^{\psi-1} .
$$

\section{Choice of Corporate Governance Investments}

Consider next the skill level $\widetilde{s}$ above that firms do not invest into corporate governance. According to proposition 1 this cutoff is given by the firm that employs the manager with reservation wages equal to $b$ such that

$$
\varepsilon M\left(\frac{t^{\kappa}}{w}\right)^{\sigma-1} \frac{\mu}{\kappa+\mu}\left(\widetilde{s}^{(\kappa+\mu)(\sigma-1)}-s_{c}^{(\kappa+\mu)(\sigma-1)}\right)+w=b .
$$

Plugging in $M$ and the equilibrium solution for $s_{c}$ yields

$$
\varepsilon\left[\frac{\lambda}{\varepsilon} w^{\sigma} t^{-\kappa(\sigma-1)} s_{c}^{\psi-1}\right]\left(\frac{t^{\kappa}}{w}\right)^{\sigma-1} \frac{\mu}{\kappa+\mu}\left(\widetilde{s}^{(\kappa+\mu)(\sigma-1)}-s_{c}^{(\kappa+\mu)(\sigma-1)}\right)+w=b
$$

which can be simplified to

$$
\widetilde{s}=\left(1+\frac{(\kappa+\mu)(b-w)}{\lambda \mu w}\right)^{\frac{1}{1-\psi}} s_{c} .
$$

The fraction of firms that do not invest into corporate governance follows directly from $\widetilde{s}$. 


\section{Proof of Proposition 3}

Consider the effects of an increase in $\kappa$ in the model. While the labor market clearing condition is left unaffected, there are two opposing effects on the zero cutoff earnings conditions: a positive productivity effect and a negative price index effect. Since an increase in $\kappa$ disproportionally benefits the productivity of the competing firms, skillbiased technological change toughens selection. To see this, consider the selection effect $\partial s_{c} / \partial \kappa:$

$$
\begin{aligned}
\frac{\partial s_{c}}{\partial \kappa} & =\frac{\partial \psi}{\partial \kappa} \frac{\partial s_{c}}{\partial \psi} \\
& =\frac{\partial[1-(\sigma-1)(\kappa+\mu)]}{\partial \kappa} \frac{\partial\left[1+\psi^{-1}(\varepsilon(\sigma-1) \lambda)\right]}{\partial \psi} \\
& =[-(\sigma-1)]\left[-\psi^{-2}(\varepsilon(\sigma-1) \lambda)\right] \\
& =\varepsilon \lambda\left(\frac{\sigma-1}{\psi}\right)^{2}>0
\end{aligned}
$$

Next, consider the effect of skill-biased technological change on the aggregate expenditure level $X$ :

$$
\begin{aligned}
\frac{\partial X}{\partial \kappa} & =\frac{\partial \psi}{\partial \kappa} \frac{\partial X}{\partial \psi} \\
& =\frac{\partial[1-(\sigma-1)(\kappa+\mu)]}{\partial \kappa} \frac{\partial\left[\sigma \lambda L w(\psi+\varepsilon \lambda(\sigma-1))^{-1}\right]}{\partial \psi} \\
& =[-(\sigma-1)]\left[-\sigma \lambda L w(\psi+\varepsilon \lambda(\sigma-1))^{-2}\right] \\
& =\frac{\sigma \lambda L w(\sigma-1)}{(\psi+\varepsilon \lambda(\sigma-1))^{2}}>0
\end{aligned}
$$

In order to evaluate how skill-biased technological change affects the fraction of firms $\theta$ with no investments into corporate governance, I restate $\theta$ in the following way:

$$
\theta=\left(\frac{\lambda \mu w}{\lambda \mu w+(\kappa+\mu)(b-w)}\right)^{\frac{1}{(\kappa+\mu)(\sigma-1)}}
$$

A rise in $\kappa$ has two effects on $\theta$ : a negative bargaining effect and a positive productivity effect. The negative bargaining effect is captured by an increase of the denominator such that $\theta$ decreases. The positive productivity effect is captured by the decrease of the exponent such that $\theta$ rises.

In order to evaluate the sign of the overall effect, I take the logarithm of $\theta$ and consider 
its derivative $\nabla(\kappa)$ :

$$
\begin{aligned}
\nabla(\kappa) & \equiv \frac{\partial \ln (\theta)}{\partial \kappa} \\
& =\frac{\partial\left(\ln \left(\left(\frac{\lambda \mu w+(\kappa+\mu)(b-w)}{\lambda \mu w}\right)^{-\frac{1}{(\kappa+\mu)(\sigma-1)}}\right)\right)}{\partial \kappa} \\
& =\frac{\partial\left(\frac{1}{-(\kappa+\mu)(\sigma-1)} \ln \left(\frac{\lambda \mu w+(\kappa+\mu)(b-w)}{\lambda \mu w}\right)\right)}{\partial \kappa} .
\end{aligned}
$$

Using the product and chain rule gives

$$
\begin{aligned}
\frac{\partial\left(\frac{1}{-(\kappa+\mu)(\sigma-1)} \ln \left(\frac{\lambda \mu w+(\kappa+\mu)(b-w)}{\lambda \mu w}\right)\right)}{\partial \kappa}= & (\kappa+\mu)^{-2}(\sigma-1)^{-1} \ln \left(\frac{\lambda \mu w+(\kappa+\mu)(b-w)}{\lambda \mu w}\right) \\
& -\frac{1}{(\kappa+\mu)(\sigma-1)} \frac{(b-w)}{\lambda \mu w+(\kappa+\mu)(b-w)} \\
= & \frac{1}{(\kappa+\mu)(\sigma-1)}\left(\frac{1}{(\kappa+\mu)} \ln \left(\frac{\lambda \mu w+(\kappa+\mu)(b-w)}{\lambda \mu w}\right)\right. \\
& \left.-\frac{b-w}{\lambda \mu w+(\kappa+\mu)(b-w)}\right),
\end{aligned}
$$

where the term $\ln \left(\frac{\lambda \mu w+(\kappa+\mu)(b-w)}{\lambda \mu w}\right)$ captures the positive productivity effect while the term $-\frac{(\kappa+\mu)(b-w)}{\lambda \mu w+(\kappa+\mu)(b-w)}$ corresponds to the negative bargaining effect.

This positive productivity effect outweighs the negative bargaining effect if and only if

$$
\ln \left(\frac{\lambda \mu w+(\kappa+\mu)(b-w)}{\lambda \mu w}\right)>\frac{(\kappa+\mu)(b-w)}{\lambda \mu w+(\kappa+\mu)(b-w)}
$$

which is always fulfilled since the left hand side of this inequality is strictly larger than one while the right hand side is always strictly smaller than one. Consequently, skill-biased technological change unambiguously increases the share of firms with $g=0$ in equilibrium.

\section{Proof of Proposition 4}

\section{Derivation of the Equilibrium}

Since firms face identical demand elasticities in both markets, the operating profit ratio of a marginal exporter and a marginal domestic firm can be stated as

$$
\frac{\varepsilon Y_{x}\left(s_{x}\right)}{\varepsilon Y_{d}\left(s_{d}\right)}=\frac{\varepsilon \tau^{1-\sigma} M\left(\frac{t^{\kappa} s_{x}^{\kappa+\mu}}{w}\right)^{\sigma-1}}{\varepsilon M\left(\frac{t^{\kappa} s_{d}^{\kappa+\mu}}{w}\right)^{\sigma-1}}=\frac{f w}{\left(\left(1-\frac{w}{b}\right)(m-(1-\varepsilon) l)+1\right) w}
$$


which yields $s_{x}=\left(\frac{\tau^{\sigma-1} f}{\lambda}\right)^{\frac{1}{1-\psi}} s_{d}$. After exchanging variables and integrating over the skill distribution, the price index $P$ in the open economy with two identical countries can be written as follows:

$$
\begin{aligned}
P & =\left[\int_{s_{d}}^{\infty}\left(\frac{\sigma}{\sigma-1} w t^{-\kappa} s^{-(\kappa+\mu)}\right){ }^{1-\sigma} d \varepsilon L\left(1-s^{-1}\right)+\int_{s_{x}}^{\infty}\left(\tau \frac{\sigma}{\sigma-1} w t^{-\kappa} s^{-(\kappa+\mu)}\right) 1-\sigma \sigma d \varepsilon L\left(1-s^{-1}\right)\right]^{1 /(1-\sigma)} \\
& =w t^{-\kappa} \frac{\sigma}{\sigma-1}\left(\frac{\psi}{\varepsilon L}\right)^{\frac{1}{\sigma-1}} s_{d}^{\frac{\psi}{\sigma-1}}\left[1+\tau^{-\frac{1}{\kappa+\mu}} f^{\frac{-\psi}{1-\psi}} \lambda^{\frac{\psi}{1-\psi}}\right]^{1 /(1-\sigma)} .
\end{aligned}
$$

Next, use the index of bilateral distance $\Delta \equiv \tau^{\frac{1}{\kappa+\mu}} f^{\frac{\psi}{1-\psi}}$ to restate the open economy version of $P$ as follows:

$$
P=\frac{\sigma}{\sigma-1} w t^{-\kappa}\left(\frac{\psi}{\varepsilon L}\right)^{\frac{1}{\sigma-1}} s_{d}^{\frac{\psi}{\sigma-1}}\left[1+\lambda^{\frac{\psi}{1-\psi}} \Delta^{-1}\right]^{1 /(1-\sigma)}
$$

Then, I derive the zero cutoff earnings condition for the open economy case. Again, the marginal firm is just breaks even such that $\varepsilon Y\left(s_{d}\right)=\left(1-\frac{w}{b}\right)(m-(1-\varepsilon) l) w+w$. The left hand side can be written in terms of $X$ and $s_{d}$ such that:

$$
\varepsilon Y\left(s_{d}\right)=\varepsilon M\left(\frac{t^{\kappa} s_{d}^{\kappa+\mu}}{w}\right)^{\sigma-1}=X \frac{\psi}{\sigma L}\left[1+\lambda^{\frac{\psi}{1-\psi}} \Delta^{-1}\right]^{-1} s_{d}
$$

Setting this equal to $\left(1-\frac{w}{b}\right)(m-(1-\varepsilon) l) w+w$ yields the zero cutoff earnings condition for the open economy

$$
\begin{aligned}
X \frac{\psi}{\sigma L}\left[1+\lambda^{\frac{\psi}{1-\psi}} \Delta^{-1}\right]^{-1} s_{d} & =\left(\left(1-\frac{w}{b}\right)(m-(1-\varepsilon) l)+1\right) w \\
X & \Longleftrightarrow \frac{\sigma L \lambda w}{\psi}\left[1+\lambda^{\frac{\psi}{1-\psi}} \Delta^{-1}\right] s_{d}^{-1}
\end{aligned}
$$

The labor market clearing condition now requires to incorporate earnings from production workers that are employed to produce output for the foreign market or for the fix investment to gain market access. However, the term for the aggregate earnings of production workers remains unchanged compared to the closed economy case at $L w\left(1-s_{d}^{-1}\right)$.

$$
\int_{0}^{L s_{d}^{-1}}\left[\varepsilon \frac{\sigma-1}{\sigma} X P^{\sigma-1} p_{j}^{1-\sigma}\right] d j+\int_{0}^{L s_{x}^{-1}}\left[\varepsilon \frac{\sigma-1}{\sigma} X P^{\sigma-1} \tau^{1-\sigma} p_{j}^{1-\sigma}\right] d j+f w L s_{x}^{-1}=L w\left(1-s_{d}^{-1}\right) .
$$


The left hand side (aggregate production labor expenditure) may be simplified as follows:

$$
\begin{aligned}
& \int_{0}^{L s_{d}^{-1}}\left[\varepsilon \frac{\sigma-1}{\sigma} X P^{\sigma-1} p_{j}^{1-\sigma}\right] d j+\int_{0}^{L s_{x}^{-1}}\left[\varepsilon \frac{\sigma-1}{\sigma} X P^{\sigma-1} \tau^{1-\sigma} p_{j}^{1-\sigma}\right] d j+f w L s_{x}^{-1} \\
= & \varepsilon \frac{\sigma-1}{\sigma} X P^{\sigma-1}\left[\int_{0}^{L s_{d}^{-1}} p_{j}^{1-\sigma} d j+\tau^{1-\sigma} \int_{0}^{L s_{x}^{-1}} p_{j}^{1-\sigma} d j\right]+f w L s_{x}^{-1} \\
= & \varepsilon \frac{\sigma-1}{\sigma} X P^{\sigma-1}\left[\left(\frac{\sigma}{\sigma-1} w t^{-\kappa}\right)^{1-\sigma}\left(\frac{\psi}{\varepsilon L}\right)^{-1} s_{d}^{-\psi}\left(1+\lambda^{\frac{\psi}{1-\psi}} \Delta^{-1}\right)\right]+f w L s_{x}^{-1} \\
= & \varepsilon \frac{\sigma-1}{\sigma} X+f w L s_{x}^{-1} .
\end{aligned}
$$

Setting this term for the aggregate expenditure on production labor equal to the total earnings of production workers leads to $\varepsilon \frac{\sigma-1}{\sigma} X+f w L s_{x}^{-1}=L w\left(1-s_{d}^{-1}\right)$ and after replacing $s_{x}$ one obtains

$$
\begin{aligned}
\varepsilon \frac{\sigma-1}{\sigma} X+f w L\left(\frac{\tau^{\sigma-1} f}{\lambda}\right)^{\frac{1}{\psi-1}} s_{d}^{-1} & =L w\left(1-s_{d}^{-1}\right) \\
& \Longleftrightarrow \\
X & =\frac{\sigma}{\sigma-1} \frac{L}{\varepsilon} w\left(1-s_{d}^{-1}\left(1+\lambda^{\frac{1}{1-\psi}} \Delta^{-1}\right)\right) .
\end{aligned}
$$

Setting both equilibrium conditions equal allows to solve first for the domestic cutoff management skill $s_{d}$ and the aggregate expenditure level $X$. Consider first the skill level $s_{d}$ :

$$
\begin{aligned}
\frac{\sigma L \lambda w}{\psi}\left[1+\lambda^{\frac{\psi}{1-\psi}} \Delta^{-1}\right] s_{d}^{-1} & =\frac{\sigma}{\sigma-1} \frac{L}{\varepsilon} w\left(1-\underline{s}_{d}^{-1}\left(1+\lambda^{\frac{1}{1-\psi}} \Delta^{-1}\right)\right) \\
& \Longleftrightarrow 1+\frac{\varepsilon \lambda(\sigma-1)}{\psi}+\left(1+\frac{\varepsilon(\sigma-1)}{\psi}\right) \lambda^{\frac{1}{1-\psi}} \Delta^{-1} \\
s_{d} & =1
\end{aligned}
$$

Note that the domestic cutoff management skill increases whenever economic distance falls and that $\lim _{\Delta \rightarrow \infty} s_{d}=s_{c}$. Plug the solution for $s_{d}$ into the zero cutoff earnings condition to obtain $X$ :

$$
\begin{aligned}
X & =\frac{\sigma L \lambda w}{\psi}\left(1+\lambda^{\frac{\psi}{1-\psi}} \Delta^{-1}\right)\left(1+\frac{\varepsilon \lambda(\sigma-1)}{\psi}+\left(1+\frac{\varepsilon(\sigma-1)}{\psi}\right) \lambda^{\frac{1}{1-\psi}} \Delta^{-1}\right)^{-1} \\
& =\frac{\sigma L \lambda w\left(1+\lambda^{\frac{\psi}{1-\psi}} \Delta^{-1}\right)}{\psi+\varepsilon \lambda(\sigma-1)+(\psi+\varepsilon(\sigma-1)) \lambda^{\frac{1}{1-\psi}} \Delta^{-1}} .
\end{aligned}
$$

Also the aggregate expenditure level equals the expenditure level in the closed economy case when the index of economic distance $\Delta$ approaches infinity. Furthermore, note that 
aggregate expenditure is larger when the economies are less integrated $\left(\frac{\partial X}{\partial \Delta}>0\right)$ since

$$
\frac{\partial X}{\partial \Delta}=\frac{\lambda L \sigma \psi w\left(\lambda^{\frac{1}{1-\psi}}-\lambda^{\frac{\psi}{1-\psi}}\right)}{\left(\Delta(\varepsilon \lambda(\sigma-1)+\psi)+\lambda^{\frac{1}{1-\psi}}(\psi+\varepsilon(\sigma-1))\right)^{2}}>0
$$

The effective market size $M$ of a firm in equilibrium can again be stated as in the closed economy:

$$
\begin{aligned}
M \equiv & \frac{1}{\sigma}\left(\frac{\sigma}{\sigma-1}\right)^{1-\sigma} X P^{\sigma-1} \\
= & \frac{1}{\sigma}\left(\frac{\sigma}{\sigma-1}\right)^{1-\sigma}\left[\frac{\sigma L \lambda w\left(1+\lambda^{\frac{\psi}{1-\psi}} \Delta^{-1}\right)}{\psi+\varepsilon \lambda(\sigma-1)+(\psi+\varepsilon(\sigma-1)) \lambda^{\frac{1}{1-\psi}} \Delta^{-1}}\right] \\
& {\left[\frac{\sigma}{\sigma-1} w t^{-\kappa}\left(\frac{\psi}{\varepsilon L}\right)^{\frac{1}{\sigma-1}} s_{d}^{\frac{\psi}{\sigma-1}}\left[1+\lambda^{\frac{\psi}{1-\psi}} \Delta^{-1}\right]^{\frac{1}{1-\sigma}}\right]^{\sigma-1} } \\
= & \frac{\lambda}{\varepsilon} w^{\sigma} t^{-\kappa(\sigma-1)} s_{d}^{\psi-1} .
\end{aligned}
$$

\section{Effects of a Trade Integration}

Consider the effect of a trade integration $(\Delta \downarrow)$ on the fraction of firms with no investments into corporate governance $\theta .2$ different scenarios need to be distinguished:

1. low trade openness: the fix and/or variable trade costs are large that only the must productive firms choose to serve the export markets such that the sorting of cutoff skill levels is $s_{d}<\widetilde{s}<s_{x}$.

2. high trade openness: the fix and/or variable trade costs are sufficiently small that relatively many firms choose to serve the export markets such that the sorting of cutoff skill levels is $s_{d}<s_{x}<\widetilde{s}$.

Low Trade Openness The cutoff $\widetilde{s}$ can be evaluated as in the closed economy case

$$
\begin{aligned}
\varepsilon M\left(\frac{t^{\kappa}}{w}\right)^{\sigma-1} \frac{\mu}{\kappa+\mu}\left(\widetilde{s}^{(\kappa+\mu)(\sigma-1)}-s_{d}^{(\kappa+\mu)(\sigma-1)}\right)+w & =b \\
\left(\frac{\widetilde{s}}{s_{d}}\right)^{1-\psi} & =1+\frac{(\kappa+\mu)(b-w)}{\lambda \mu w} \\
\widetilde{s} & =\left(1+\frac{(\kappa+\mu)(b-w)}{\lambda \mu w}\right)^{\frac{1}{1-\psi}} s_{d} .
\end{aligned}
$$


High Trade Openness The cutoff $\widetilde{s}$ in the open economy case is

$$
\begin{aligned}
\varepsilon M\left(\frac{t^{\kappa}}{w}\right)^{\sigma-1} \frac{\mu}{\kappa+\mu}\left(\left(\tilde{s}^{1-\psi}-s_{d}^{1-\psi}\right)+\tau^{1-\sigma}\left(\tilde{s}^{1-\psi}-s_{x}^{1-\psi}\right)\right)+w & =b \\
\left(\frac{\widetilde{s}}{s_{d}}\right)^{1-\psi}\left(1+\tau^{1-\sigma}\right) & =\frac{(\kappa+\mu)(b-w)}{\lambda \mu w}-\frac{\lambda}{\tau^{2(\sigma-1) f}}+1
\end{aligned}
$$

such that $\widetilde{s}$ and $\theta$ are:

$$
\begin{aligned}
& \widetilde{s}=\left(\left(\frac{(\kappa+\mu)(b-w)+\lambda \mu w}{\lambda \mu w}-\frac{\lambda}{\tau^{2(\sigma-1) f}}\right)\left(\frac{1}{1+\tau^{1-\sigma}}\right)\right)^{\frac{1}{1-\psi}} s_{d} \\
& \theta=\left(\left(\frac{(\kappa+\mu)(b-w)+\lambda \mu w}{\lambda \mu w}-\frac{\lambda}{\tau^{2(\sigma-1) f}}\right)\left(\frac{1}{1+\tau^{1-\sigma}}\right)\right)^{-\frac{1}{(\kappa+\mu)(\sigma-1)}} .
\end{aligned}
$$

From there, it follows that $\frac{\partial \theta}{\partial \Delta}<0$.

\section{Data Appendix}

\section{Preparation of the BoardEx Data}

Before compensation data from BoardEx could be applied in the empirical models, a number of preparation steps were necessary. Since BoardEx includes both, executives and supervisory managers, the latter were excluded from the sample throughout. Furthermore, BoardEx reports several distinct incomes for some executives that hold different positions within the board of the same firm. Those incomes have been aggregated at the manager-firm-year level to obtain the aggregate executive compensation. The next step of preparation involved the deletion of double entries: Although most data items stem from annual report data, there is also some reporting from quarterly announcements included. Those data points from quarterly announcements have been excluded. Furthermore, reporting periods have been assimilated by switching from accounting periods which start at different months depending on each firm in the sample to calendar years. Since job titles are not perfectly consistent, CEOs were identified as the highest paid executive in each firm in a given year.

\section{Construction of the Instrumental Variables}

\section{Real Effective Exchange Rate Baskets}

One variable that I use as an instrument for trade openness is the weighted average of real effective exchange rates $r_{t}(c)$ of the top 5 U.S. export destinations $c$ : Canada, Mexico, 
Great Britain, China and Japan. Each weight $\alpha_{j}(c)$ is the average country c's share of exports relative to the total exports of those five countries from the U.S. during 1991 1995 at the industry level $j$ (at the SIC 4-digit level):

$$
\begin{aligned}
\alpha_{j}(c) & =\frac{\varnothing \operatorname{exports}_{j}(c)}{\sum_{c=1}^{5} \varnothing \operatorname{exports}_{j}(c)} \\
R E E R_{j t} & =\sum_{c=1}^{5} \alpha_{j}(c) r_{t}(c)
\end{aligned}
$$

\section{Maritime Transport Costs}

The data on maritime transport costs are obtained from the OECD. A detailed description of the database is provided in Korinek (2011). Importer is the European Union (EU15) and exporter are the United States. The data measure ad valorem maritime transport costs for container trade at the commodity level. Commodities are classified based on the HS-1998 6-digit classification and where matched to SIC 4-digit industries.

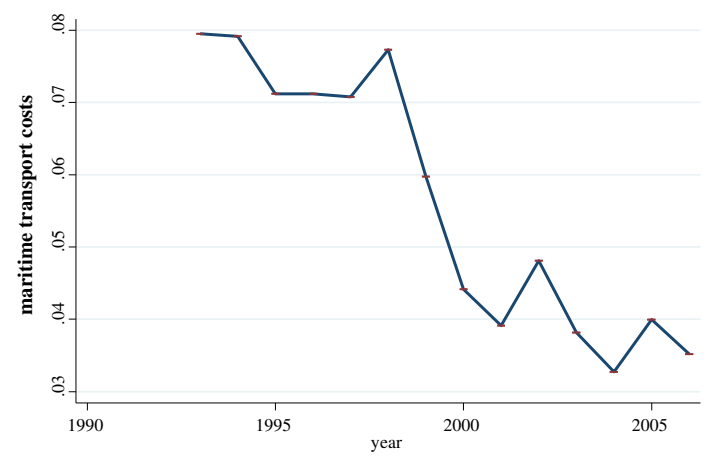

Figure 4: Maritime transport costs in value added container trade from the U.S. to Europe. 
Table 3: Summary Statistics

\begin{tabular}{lrrrrr}
\hline \hline \multicolumn{1}{c}{ variable } & observations & mean & min & max & std. dev. \\
\hline entrenchment index & 12,045 & 2.32 & 0 & 6 & 1.34 \\
ln CEO total pay & 13,675 & 8.35 & 0 & 15.08 & 1.24 \\
ln CEO equity pay & 12,442 & 8.00 & -1.10 & 15.08 & 1.55 \\
ln openness & 19,714 & -2.41 & -9.45 & 0.654 & 1.30 \\
IT investment intensity & 60,367 & 0.0906 & 0.00022 & 0.209 & 0.060 \\
ln tfp index & 22,196 & 0.2005 & -0.749 & 3.79 & 0.758 \\
ln firm labor productivity & 34,282 & 4.36 & -2.65 & 11.46 & 1.03 \\
ln total assets & 42,724 & 13.68 & -4.34 & 21.36 & 1.87 \\
total investment return & 39,904 & 0.73 & -0.9999 & 5144.16 & 35.25 \\
REER basket & 23,052 & 99.60 & 72.25 & 157.90 & 8.72 \\
maritime transport costs & 18,469 & 0.04151 & 0.00015 & 16.97 & 0.18 \\
\hline
\end{tabular}


Table 4: Description of Variables

\begin{tabular}{ll}
\hline \hline variable & description \\
\hline entrenchment & Entrenchment index from Bebchuk et al. (2009). The index ranges from 0 (good \\
& corporate governance - little entrenchment) to 6 (bad corporate governance - large \\
& entrenchment) and counts how many of the following attributes are applied in a \\
& company in a given year: staggered boards, limits to shareholder bylaw amendments, \\
& poison pills, golden parachutes, and supermajority requirements for mergers as well as \\
& for charter amendments. Information on the six different governance attributes is \\
& provided by the IRRC and includes S\&P 500 firms and other large U.S. firms. \\
& Data source: http://www.law.harvard.edu/faculty/bebchuk/data.shtml
\end{tabular}

ln CEO total Natural logarithm of the total compensation in 1000 USD of the highest-paid officer in pay the firm during a given year.

Data source: BoardEx database

ln CEO equity Natural logarithm of the equity-linked compensation in 1000 USD of the highest-paid pay officer in the firm during a given year.

Data source: BoardEx database

ln openness Natural logarithm of openness in \%, where openness is exports/(domestic shipments + imports). All variables are at the 4-digit SIC industry level for the main industry of each firm in the sample.

Data sources: exports and imports are obtained from the UN COMTRADE WITS

database http://wits.worldbank.org/; domestic shipments are from the NBER CES Manufacturing Industry database http://www.nber.org/nberces/

IT investment Share of I.T. investments in total capital formation for the main industry of the firm at intensity the ISIC Rev. 3 2-digit level.

Data source: http://www.euklems.net/

ln tfp index Natural logarithm of a total factor productivity index on the SIC 4-digit level based on 4 factors of production (production workers, non-production workers, material inputs, capital) with the base year 1987, where the index takes the value 1 .

Data source: NBER-CES Mft. Industry database http://www.nber.org/nberces/

ln firm labor Natural logarithm of the difference between sales and costs of goods sold per employee. productivity Data source: Thomson Worldscope database

ln total assets Natural logarithm of total firm assets in 1000 USD.

Data source: Thomson Worldscope database

total investment Stock return in \% corrected for dividend payments. total investment return $=100 \% \mathrm{x}$ return

((market price year end + dividends p. share + special dividends) / last year's market price year end) - 1)

Data source: Thomson Worldscope database

REER basket weighted average of the real effective exchange rates of top 5 U.S. trading partners Canada, Mexico, Great Britain, China and Japan. Weights are the country share of U.S. imports during 1991-1995 at the SIC 4-digit level. REER are domestic prices relative to the world price (larger REER means greater comparative advantage for the U.S.) Data source: weights are obtained from COMTRADE WITS; exchange rate from the BRUEGEL REER database.

maritime

Ad valorem maritime transport costs for container shipments from the U.S. to EU15 at transport costs the 4-digit SIC industry level for the main industry of each firm in the sample.

Data source: OECD MTC database 